Article

\title{
From Discrete Complexes to Metal-Organic Layered Materials: Remarkable Hydrogen Bonding Frameworks
}

\author{
Carla Queirós, Ana M. G. Silva ${ }^{\circledR}$, Baltazar de Castro and Luís Cunha-Silva *๑ \\ LAQV/REQUIMTE \& Department of Chemistry and Biochemistry, Faculty of Sciences, University of Porto, \\ 4169-007 Porto, Portugal; cpaqueiros@gmail.com (C.Q.); ana.silva@fc.up.pt (A.M.G.S.); bcastro@fc.up.pt (B.d.C.) \\ * Correspondence: 1.cunha.silva@fc.up.pt; Tel.: +351-220402576
}

Academic Editors: Filipe Alexandre Almeida Paz and Igor Djerdj

Received: 31 January 2020; Accepted: 12 March 2020; Published: 16 March 2020

\begin{abstract}
A series of metal-organic coordination complexes based on alkaline-earth metal centers $[\mathrm{Mg}(\mathrm{II}), \mathrm{Ca}(\mathrm{II})$, and $\mathrm{Ba}(\mathrm{II})]$ and the ligand 5-aminoisophthalate (aip ${ }^{2-}$ ) revealed notable structural diversity, both in the materials' dimensionality and in their hydrogen bonding networks: $\left[\mathrm{Mg}\left(\mathrm{H}_{2} \mathrm{O}\right)_{6}\right] \cdot\left[\mathrm{Mg}_{2}(\right.$ Haip $\left.)\left(\mathrm{H}_{2} \mathrm{O}\right)_{10}\right] \cdot\left(\right.$ Haip) $\cdot 3($ aip $) \cdot 10\left(\mathrm{H}_{2} \mathrm{O}\right)$ (1) and $\left[\mathrm{Mg}(\right.$ aip $)($ phen $\left.)\left(\mathrm{H}_{2} \mathrm{O}\right)_{2}\right] \cdot\left(\mathrm{H}_{2} \mathrm{O}\right)(2)$ were isolated as discrete complexes (0D); $\left[\mathrm{Ca}(\right.$ aip $\left.)\left(\mathrm{H}_{2} \mathrm{O}\right)_{2}\right] \cdot\left(\mathrm{H}_{2} \mathrm{O}\right)(3)$, $\left[\mathrm{Ca}(\right.$ aip $)($ phen $\left.)\left(\mathrm{H}_{2} \mathrm{O}\right)_{2}\right] \cdot($ phen $) \cdot\left(\mathrm{H}_{2} \mathrm{O}\right)(4)$, and $\left[\mathrm{Ba}_{2}(\text { aip })_{2}(\text { phen })_{2}\left(\mathrm{H}_{2} \mathrm{O}\right)_{7}\right] \cdot 2($ phen $) \cdot 2\left(\mathrm{H}_{2} \mathrm{O}\right)(5)$ revealed metal-organic chain (1D) structures, while the $\left[\mathrm{Ba}(\right.$ aip $\left.)\left(\mathrm{H}_{2} \mathrm{O}\right)\right](6)$ showed a metal-organic layered (2D) arrangement. Furthermore, most of these metal-organic coordination materials revealed interesting thermal stability properties, being stable at temperatures up to $450{ }^{\circ} \mathrm{C}$.
\end{abstract}

Keywords: metal-organic framework; alkaline-earth metals; benzenedicarboxylate ligands; crystal structure; structural diversity; hydrogen bonding networks

\section{Introduction}

Polyfunctional rigid aromatic carboxylate ligands are frequently used in the synthesis of new coordination polymers (CPs), frequently designated as metal-organic frameworks (MOFs) due to the interest in the production of new functional materials [1,2]. In the last years, an enormous number of works have been published using benzenecarboxylic acids [3,4], such as, 1,3,5-benzenetricarboxylic acid ( $\left.\mathrm{H}_{3} \mathrm{BTC}\right)[5,6], 1,3$-benzenedicarboxylic acid ( $m$ - $\left.\mathrm{H}_{2} \mathrm{BDC}\right)$ [7,8], 1,4-benzenedicarboxylic acid ( $p-\mathrm{H}_{2} \mathrm{BDC}$, terephthalic acid) [9,10], and their amino-substituted derivatives [11,12].

5-Aminoisophthalic acid ( $\mathrm{H}_{2}$ aip, Scheme 1$)$ is becoming a ligand with increasing importance in materials science, since it can adopt several coordination modes, associated with the two carboxylate groups and the amino function [13]. Recently, several CPs based on $\mathrm{H}_{2}$ aip derivatives have been prepared [14-17]; however, additional research of these materials is crucial, especially concerning post-functionalization procedures and the development of derivatives with different bases, with the main goal of enhancing their applicability in several technological areas, including gas adsorption and photoluminescence.

In the last decade, the use of alkaline-earths as metal centers in materials' syntheses has become more common due to the development of novel synthetic methodologies, including mechanochemical and ultrasonical synthesis $[18,19]$, that circumvent the limitations associated to their synthesis, like low solubility [20]. The use of anionic oxygen ligands is known to promote the syntheses of coordination polymers with different dimensionality. Therefore, several MOFs with alkaline-earth metals coordinated to carboxylate ligands have been reported [21-23]. Some of their properties include catalytic activity, luminescence, increased thermal stability, and biological potentialities. The most important 
disadvantages in the use of alkaline-earth metals are the unexpected geometries and coordination numbers of the final structures, as their bonding is not affected by ligand field stabilization [24,25] contrarily to transition or lanthanide metal ions. MOFs containing alkaline-earth metals can find application in numerous fields, such as superconduction, metallic conduction, ferroelectric, and catalysis and can present interesting architectures with appealing properties [1,20,26-30]. For the majority of the elements of group 2, some of those properties include aqueous solubility, non-toxicity, and lower cost, representing an important advantage relative to transition or lanthanide metal ions, especially for dyes/pigments industries [20].<smiles>Nc1cc(C(=O)O)cc(C(=O)O)c1</smiles>

Scheme 1. 5-aminoisophthalic acid ( $\mathrm{H}_{2}$ aip) chemical structure.

Considering the lower cost associated to alkaline earths-based materials, several reports of their applicability in distinct technological areas [31-35], and our research interest in multifunctional MOF-based materials [17,36-41], a series of metal-organic coordination complexes based on Mg(II), $\mathrm{Ca}(\mathrm{II})$, and $\mathrm{Ba}(\mathrm{II})$ was prepared and structurally characterized. The materials revealed an interesting structural diversity including discrete complexes (0D), metal-organic chains (1D), and metal-organic layers (2D), as well as remarkable hydrogen bonding frameworks. The thermal stability was further investigated by thermogravimetric analysis (TGA).

\section{Results and Discussion}

\subsection{Syntheses of the Complexes and Materials}

The development and preparation of new metal-organic coordination materials based on alkaline earth (AE) metal ions and $\mathrm{H}_{2}$ aip were performed using different synthetic protocols, including conventional heating and hydrothermal/solvothermal synthesis (the conditions used are summarized in Table 1). A series of AE-aip-based multidimensional metal-organic coordination complexes were isolated as crystalline materials suitable for single-crystal XRD analysis. Their solid-state structures were determined, confirming the formation of compounds with distinct dimensionalities: Discrete complexes (0D), $\left[\mathrm{Mg}\left(\mathrm{H}_{2} \mathrm{O}\right)_{6}\right] \cdot\left[\mathrm{Mg}_{2}(\mathrm{Haip})\left(\mathrm{H}_{2} \mathrm{O}\right)_{10}\right] \cdot\left(\right.$ Haip) $3($ aip $) \cdot 10\left(\mathrm{H}_{2} \mathrm{O}\right)(\mathbf{1})$ and $\left[\mathrm{Mg}(\right.$ aip $)($ phen $\left.)\left(\mathrm{H}_{2} \mathrm{O}\right)_{2}\right] \cdot\left(\mathrm{H}_{2} \mathrm{O}\right)$ (2), metal-organic chains (1D), [Ca(aip) $\left.\left(\mathrm{H}_{2} \mathrm{O}\right)_{2}\right] \cdot\left(\mathrm{H}_{2} \mathrm{O}\right)(3),\left[\mathrm{Ca}(\right.$ aip $)($ phen $\left.)\left(\mathrm{H}_{2} \mathrm{O}\right)_{2}\right] \cdot($ phen $) \cdot\left(\mathrm{H}_{2} \mathrm{O}\right)(4)$, and $\left.\left[\mathrm{Ba}_{2}(\text { aip })_{2} \text { (phen }\right)_{2}\left(\mathrm{H}_{2} \mathrm{O}\right)_{7}\right] \cdot 2($ phen $) \cdot 2\left(\mathrm{H}_{2} \mathrm{O}\right)(5)$, as well as a metal-organic layer $(2 \mathrm{D})\left[\mathrm{Ba}(\right.$ aip $\left.)\left(\mathrm{H}_{2} \mathrm{O}\right)\right]$ (6), where phen is 1,10-phenanthroline. Additionally, all the materials were characterized by FT-IR spectroscopy and their thermal stability investigated by thermogravimetric analysis (TGA).

Table 1. Conditions of the synthetic protocols used in the preparation of diverse materials using $\mathrm{H}_{2}$ aip and alkaline earth metals.

\begin{tabular}{cccc}
\hline $\begin{array}{c}\text { Compound/ } \\
\text { Dimensionality }\end{array}$ & Heating Method & $\begin{array}{c}\text { Metal Ion/ } \\
\text { Co-Ligand }\end{array}$ & Conditions \\
\hline 1/0D & Conventional & $\mathrm{Mg}(\mathrm{II})$ & $323 \mathrm{~K}, 65 \mathrm{~h}$ \\
2/0D & Hydrothermal & $\mathrm{Mg}(\mathrm{II}) /$ phen & $403 \mathrm{~K}, 72 \mathrm{~h}$ \\
3/1D & Conventional & $\mathrm{Ca}(\mathrm{II})$ & $323 \mathrm{~K}, 68 \mathrm{~h}$ \\
4/1D & Conventional & $\mathrm{Ca}(\mathrm{II}) /$ phen & $323 \mathrm{~K}, 3 \mathrm{~h}$ \\
5/1D & Conventional & $\mathrm{Ba}(\mathrm{II}) /$ phen & $323 \mathrm{~K}, 68 \mathrm{~h}$ \\
6/2D & Conventional & $\mathrm{Ba}(\mathrm{II})$ & $323 \mathrm{~K}, 65 \mathrm{~h}$ \\
\hline
\end{tabular}




\subsection{Discrete Complexes (OD)}

The crystal structure of compounds $1\left\{\left[\mathrm{Mg}\left(\mathrm{H}_{2} \mathrm{O}\right)_{6}\right] \cdot\left[\mathrm{Mg}_{2}(\mathrm{Haip})\left(\mathrm{H}_{2} \mathrm{O}\right)_{10}\right] \cdot 3\right.$ (Haip) $\cdot($ aip $\left.) \cdot 10\left(\mathrm{H}_{2} \mathrm{O}\right)\right\}$ and $2\left\{\left[\mathrm{Mg}(\text { aip })(\text { phen })\left(\mathrm{H}_{2} \mathrm{O}\right)_{2}\right]_{2} \cdot 2\left(\mathrm{H}_{2} \mathrm{O}\right)\right\}$ revealed two unprecedented binuclear discrete (0D) complexes, with interesting structural features. Compound $\mathbf{1}$ was crystallized from a water solution in the monoclinic unit cell, with the structure solved and refined in space group $P 2_{1} / c$ (see the experimental section). The asymmetric unit $(a s u)$ contains a mononuclear $\left[\mathrm{Mg}\left(\mathrm{H}_{2} \mathrm{O}\right)_{6}\right]^{2+}$ cation and a binuclear $\left[\mathrm{Mg}_{2}(\text { Haip })\left(\mathrm{H}_{2} \mathrm{O}\right)_{10}\right]^{3+}$ cationic complex, 1 partially deprotonated ligand (Haip ${ }^{-}$), and 3 fully deprotonated ligands ( aip $^{2-}$ ), as well as 10 crystallization water molecules (Figure S1 in Supplementary Materials, ESI). The three crystallographic-independent $\mathrm{Mg}^{2+}$ centers show distorted octahedral geometries being coordinated by six $\mathrm{O}$-atoms with typical $\mathrm{Mg}-\mathrm{O}$ distances and $\mathrm{O}-\mathrm{Mg}-\mathrm{O}$ angles (for details about these distances and angles, see Table S2 in Supplementary Materials). Mg3 bonds to six water molecules, leading to the formation of the $\left[\mathrm{Mg}\left(\mathrm{H}_{2} \mathrm{O}\right)_{6}\right]^{2+}$ cation, while $\mathrm{Mg} 1$ and $\mathrm{Mg} 2$ coordinate to five water molecules and an $\mathrm{O}$-atom of the carboxylate group of the same bridging Haip ${ }^{-}$ ligand originating the binuclear cationic complex $\left[\mathrm{Mg}_{2}(\mathrm{Haip})\left(\mathrm{H}_{2} \mathrm{O}\right)_{10}\right]^{3+}$ (Figure $\left.1 \mathrm{a}\right)$.

The packing arrangement of the $\left[\mathrm{Mg}\left(\mathrm{H}_{2} \mathrm{O}\right)_{6}\right]^{2+}$ cation and the binuclear cationic complex $\left[\mathrm{Mg}_{2}(\mathrm{Haip})\left(\mathrm{H}_{2} \mathrm{O}\right)_{10}\right]^{3+}$ as well as the uncoordinated $\mathrm{H}_{2}$ aip residues resembles a supramolecular layered-type structure viewed in the [1 110$]$ direction of the unit cell (Figure 1b). In fact, there is an evident alternation between organic (Haip ${ }^{-}$and aip ${ }^{2-}$ ligands) and inorganic $\left(\mathrm{Mg}^{2+}\right.$ centers and water molecules) layers along the $b$-axis, resembling a hybrid layered material. As a consequence of the large number of crystallographic-independent coordinated (16) and uncoordinated (10) water molecules, as well as several Haip ${ }^{-}$and aip $^{2-}$ ligands, the extended crystal structure of 1 shows a remarkable network of non-covalent intermolecular interactions, namely $\pi \cdots \pi$ stacking, and weak (C-H $\cdots \mathrm{O})$ and strong ( $\mathrm{N}-\mathrm{H} \cdots \mathrm{O}$ and $\mathrm{O}-\mathrm{H} \cdots \mathrm{O})$ hydrogen bonds, ultimately leading to a 3D supramolecular network (Figure 1b; for details about the geometry of the strong hydrogen bonds, see Table S2). Adjacent organic molecules (both Haip ${ }^{-}$and aip ${ }^{2-}$ ligands) interact by $\pi \cdots \pi$ stacking between the phenyl rings $\left(C_{g} \cdots C_{g}\right.$ distances ranging between 3.7941(2) and 3.9605(2) $\AA$; where $C_{g}$ represents the gravity center of the ring), leading to the formation of supramolecular infinite chains in an anti-parallel arrangement (adjacent chains are rotated by ca. $180^{\circ}$; Figure 1c). However, besides the occurrence of some cooperative $\mathrm{C}-\mathrm{H} \cdots \mathrm{O}$ weak hydrogen bonds, the crystalline packing is mostly driven by an extending network of stronger $\mathrm{N}-\mathrm{H} \cdots \mathrm{O}$ and $\mathrm{O}-\mathrm{H} \cdots \mathrm{O}$ intermolecular interactions (light blue dashed lines in Figure $1 ; \mathrm{N}-\mathrm{H} \cdots \mathrm{O}$ were not drawn). Remarkably, the cautious analysis of these interactions revealed around 80 distinct strong hydrogen bounds involving adjacent water molecules and/or organic ligands, which enforce the overall cohesion of the extended crystal structure (Table S2). In particular, the large number of crystallographically independent water molecules are engaged in cooperative water-to-water hydrogen bonding interactions, leading to the formation of distinct water clusters, such as the $\left(\mathrm{H}_{2} \mathrm{O}\right)_{22}$ (depicted in Figure 1d). Although recent reports describing a variety of discrete water clusters (for example tetramers, pentamers, hexamers, decamers, or dodecamers) and some polymeric clusters (predominantly infinite chains) [42,43], the description of large water molecule aggregates are much more limited and, to the best of our knowledge, the $\left(\mathrm{H}_{2} \mathrm{O}\right)_{22}$ cluster found in this structure is unique. 


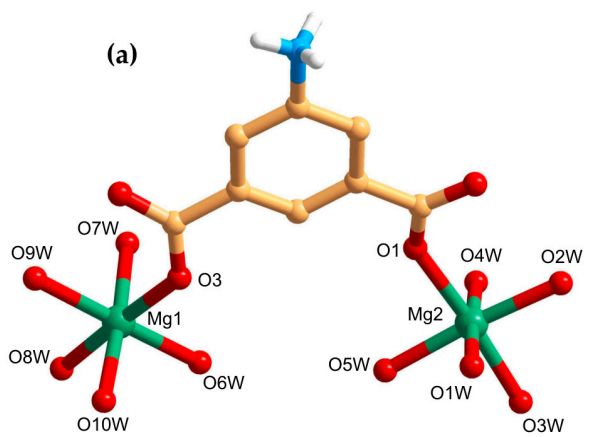

(c)

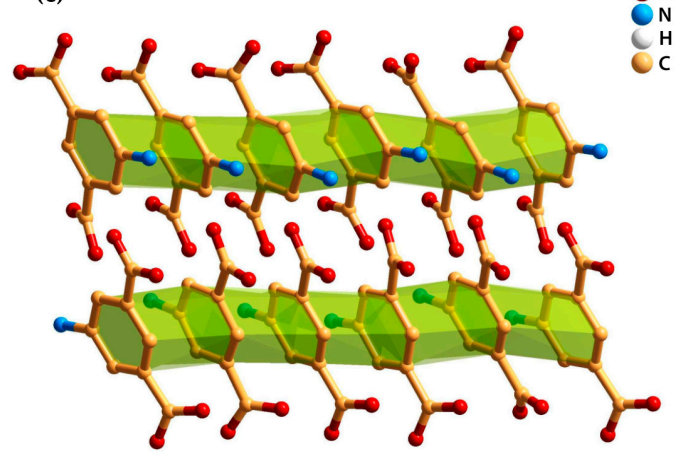

(b)
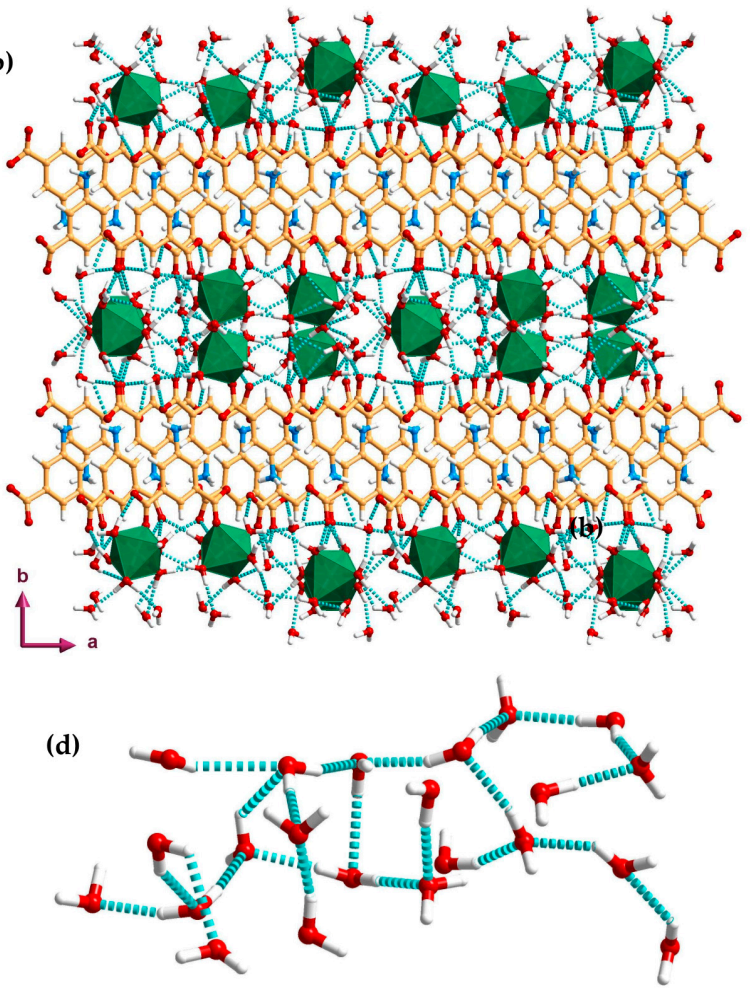

Figure 1. (a) The binuclear complex $\left[\mathrm{Mg}_{2}(\text { Haip })\left(\mathrm{H}_{2} \mathrm{O}\right)_{10}\right]^{3+}$ in the crystal structure of compound 1, showing the labelling scheme for the two $\mathrm{Mg}^{2+}$ coordination centers; other selected features of the crystal structure of 1: (b) extended packing viewed in the $\left[\begin{array}{lll}1 & 1 & 0\end{array}\right]$ direction of the unit cell; (c) $\pi \cdots \pi$ stacking between adjacent organic molecules leading to the formation of supramolecular chains; (d) the large $\left(\mathrm{H}_{2} \mathrm{O}\right) 22$ cluster $(\mathrm{O}-\mathrm{H} \cdots \mathrm{O}$ hydrogen bonds showed as light blue dashed lines).

Compound 2, formulated as $\left.\left[\mathrm{Mg}_{2}(\text { aip })_{2} \text { (phen }\right)_{2}\left(\mathrm{H}_{2} \mathrm{O}\right)_{4}\right]_{2} \cdot 2\left(\mathrm{H}_{2} \mathrm{O}\right)$, crystallized in a monoclinic unit cell and in the space group $P 21 / \mathrm{c}$. The asu contains four $\mathrm{Mg}^{2+}$ metal centers ( $\mathrm{Mg} 1, \mathrm{Mg} 2, \mathrm{Mg} 3$, and $\mathrm{Mg} 4$ ), four deprotonated ligands ( $\left(\mathrm{aip}^{2-}\right)$, four phen ligands, four lattice water molecules as well as two crystallization water molecules, forming two binuclear equivalent complexes (Figure 2a and Figure S2 in ESI). The four crystallographic independent $\mathrm{Mg}^{2+}$ centers found in the asu show similar distorted octahedral geometries being coordinated at two $\mathrm{O}$-atoms from two carboxylate groups and two water molecules ( $\mathrm{Mg}-\mathrm{O}$ distances ranging from 2.003 to $2.100 \AA$ ) and two $N$-atoms from a phen ligand ( $\mathrm{Mg}-\mathrm{N}$ distances between 2.193 to $2.230 \AA$ ). Concerning the internal angles involved in the $\mathrm{Mg}^{2+}$ coordination centers, the $\mathrm{O}-\mathrm{Mg}-\mathrm{O}$ angles are between 89.6 and $177.3^{\circ}, \mathrm{N}-\mathrm{Mg}-\mathrm{O}$ angles range from 84.39 to $97.50^{\circ}$, and the $\mathrm{N}-\mathrm{Mg}-\mathrm{N}$ angles values vary from $74.30^{\circ}$ to $75.26^{\circ}$ (for more details about these distances and angles, see Table S3 in Supplementary Material). 

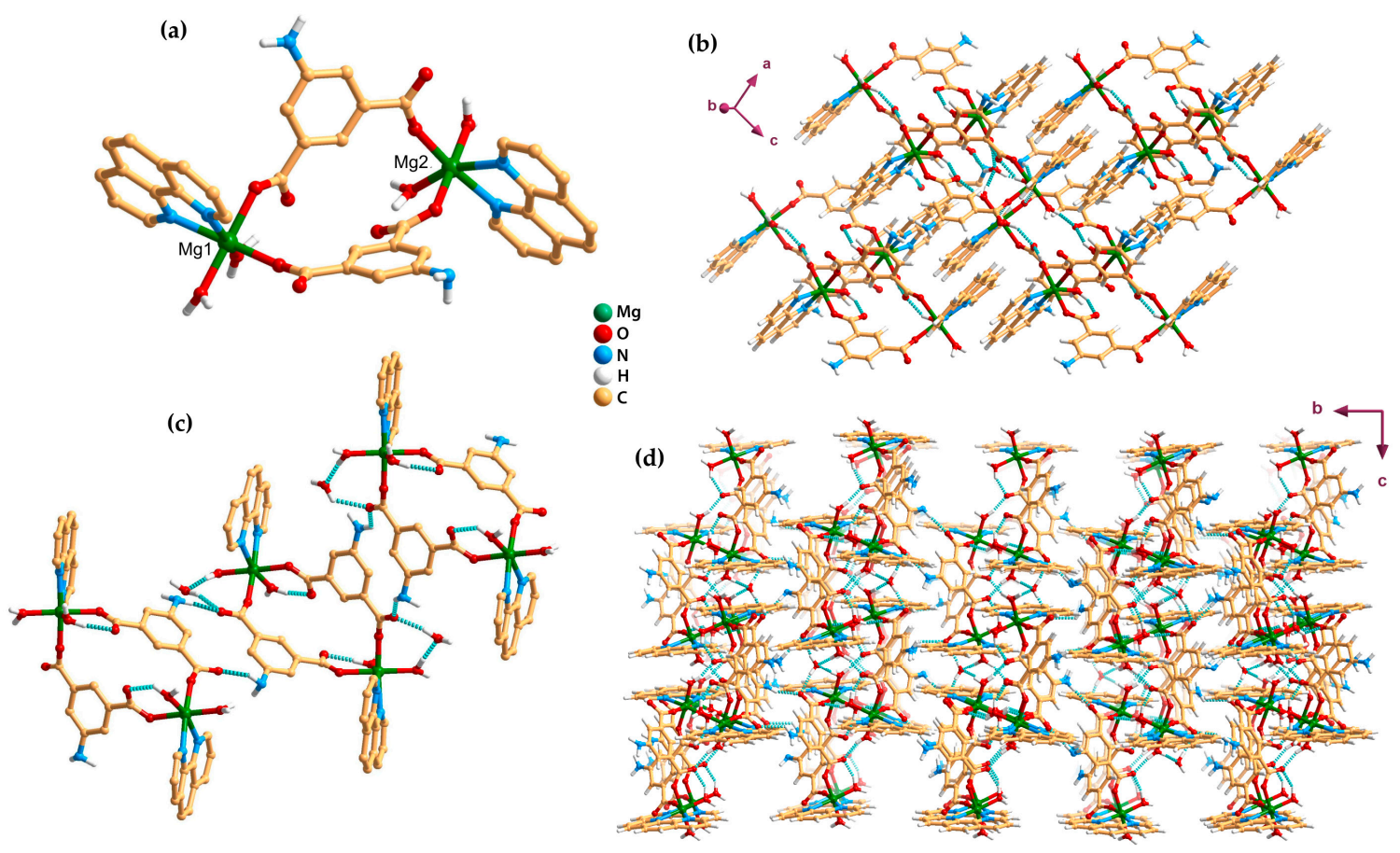

Figure 2. (a) Complex 2, $\left[\mathrm{Mg}_{2}(\text { aip })_{2}(\text { phen })_{2}\left(\mathrm{H}_{2} \mathrm{O}\right)_{4}\right]_{2} \cdot 2\left(\mathrm{H}_{2} \mathrm{O}\right)$, with the labeling scheme for the two independent $\mathrm{Mg}^{2+}$ coordination centers (geometric details about the $\mathrm{Mg}^{2+}$ coordination centers are listed in Table S1); Additional structural features of the crystal structure of 2: (b) Partial packing; (c) layered supramolecular arrangement viewed in the [1 11 1] direction of the unit cell; (d) 3D supramolecular network viewed in perspective along the a-axis of the unit cell. $\mathrm{N}-\mathrm{H} \cdots \mathrm{O}$ and $\mathrm{O}-\mathrm{H} \cdots \mathrm{O}$ hydrogen bonds are shown as blue dashed lines.

The packing arrangement of the binuclear complex 2 also reveals a layered supramolecular arrangement viewed in the [1 111 ] direction of the unit cell, creating an "upper" and "lower" layer of binuclear complex entities (Figure 2c). In comparison to 1, the distribution of the binuclear complexes seems more distorted. This distortion in the packing arrangement inhibits the $\pi \cdots \pi$ stacking since the phen molecules are displaced laterally to each other or actually in opposite directions. However, the crystal structure through $\mathrm{N}-\mathrm{H} \cdots \mathrm{O}$ and $\mathrm{O}-\mathrm{H} \cdots \mathrm{O}$ hydrogen bonds ultimately leads to a 3D supramolecular network (Figure 2d).

\subsection{Metal-Organic Chains (1D)}

The replacement of $\mathrm{Mg}^{2+}$ by $\mathrm{Ca}^{2+}$ and $\mathrm{Ba}^{2+}$ as metal centers (maintaining the organic ligand, $\mathrm{H}_{2}$ aip) in the synthetic procedures originated new metal-organic chain (1D) materials, 3, 4, and 5, using slightly different approaches. For instance, compound 3, formulated as $\left[\mathrm{Ca}(\right.$ aip $\left.)\left(\mathrm{H}_{2} \mathrm{O}\right)_{2}\right] \cdot \mathrm{H}_{2} \mathrm{O}$, was prepared by an adaptation of a published protocol [44], in which a temperature of $323 \mathrm{~K}$ was used. This value might be higher or lower than that used by the original authors, considering that the article only mentions that the solution was heated. The reaction time was increased in $16 \mathrm{~h}(64 \mathrm{~h}$ vs. $48 \mathrm{~h}$ ) and the conjunction of these reactional conditions and probably the crystallization period (around two weeks at r.t.) originated a new 1D coordination polymer.

The material 3 was isolated from a water solution, crystallized in the triclinic system, and the crystal structure solved in the centrosymmetric space group $P-1$ (see the experimental section). The asu revealed two crystallographic-independent $\mathrm{Ca}^{2+}$ centers, three fully deprotonated ligands $\left(\mathrm{aip}^{2-}\right)$, and four coordinated and two uncoordinated water molecules (Figure S3a). The two $\mathrm{Ca}^{2+}$ centers (Ca1 and Ca2) are structurally identical, since both are six coordinated and show octahedral distorted coordination geometry (Figure 3a): Each one is coordinated by three carboxylate $O$-atoms of three crystallographic-equivalent aip ${ }^{2-}$ ligands, one $\mathrm{N}$-atom from another organic ligand and two water 
molecules, $\left\{\mathrm{CaO}_{5} \mathrm{~N}\right\}$. The distorted octahedral geometry is clearly confirmed by the examination of the $\mathrm{O}-\mathrm{Ca}-\mathrm{O}$ and N-Ca-O internal angles: While the cis angles are found in the ranges 76.40(5)-103.72(4) ${ }^{\circ}$ for $\mathrm{Ca} 1$ and $79.10(5)-101.43(5)^{\circ}$ for Ca2, the trans angles range from $158.27(5)$ to $172.25(5)^{\circ}$ and $160.92(5)$ to $175.79(5)^{\circ}$ for Ca1 and Ca2, respectively (for details about these bond lengths and angles, see Table S5 in Supplementary Materials).

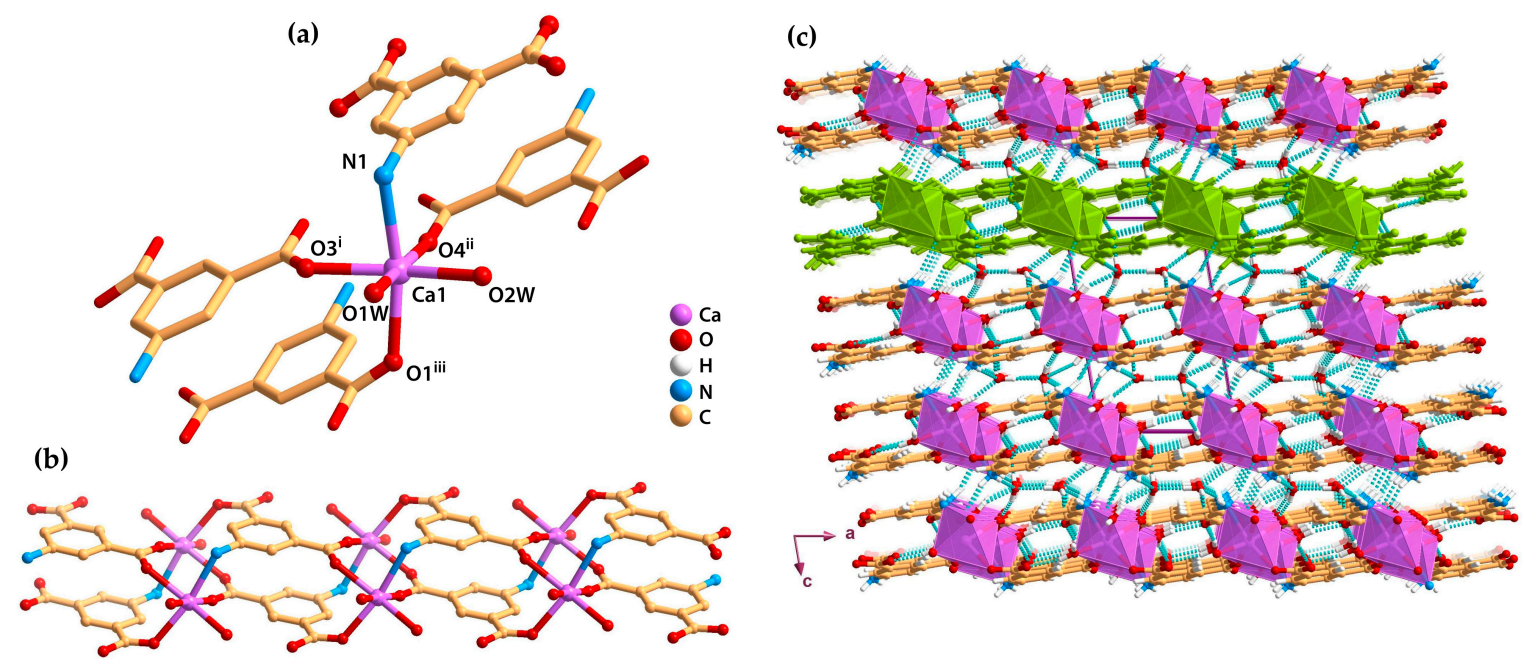

Figure 3. (a) Complete coordination environment for the Ca1 center in the crystal structure of $\left[\mathrm{Ca}\right.$ (aip) $\left.\left(\mathrm{H}_{2} \mathrm{O}\right)_{2}\right] \cdot\left(\mathrm{H}_{2} \mathrm{O}\right)(3)$, with the labelling scheme for all the atoms of the coordination sphere; (b) 1D metal-organic chain with ladder arrangement; (c) extended packing arrangement of 3 viewed in the $\left[\begin{array}{lll}0 & 1 & 0\end{array}\right]$ direction of the unit cell, with one supramolecular layer drawn in green color and $\mathrm{N}-\mathrm{H} \cdots \mathrm{O}$ and $\mathrm{O}-\mathrm{H} \cdots \mathrm{O}$ hydrogen bonds showed as the light-blue dashed line.

Each crystallographic-independent aip ${ }^{2-}$ ligand coordinates to four equivalent $\mathrm{Ca}^{2+}$ centers via three carboxylate $O$-atoms and the amino $N$-atom (see Figure S3b). The coordination behavior previously described for the metal centers and the organic ligands leads to the formation of an 1D metal-organic chain with the appearance of a ladder (Figure $3 \mathrm{~b}$ ), arranged along the $a$-axis of the unit cell. The smallest and largest $\mathrm{Ca} \cdots \mathrm{Ca}$ distances imposed within the ladder are 4.8834(5) and 8.3175(9) $\AA$, respectively. The adjacent ladders interact by strong $\mathrm{N}-\mathrm{H} \cdots \mathrm{O}$ hydrogen bonds originating 2D supramolecular structures (layers) extended in the $a b$ plane of the unit cell (Figure 3c; for geometric details about the hydrogen bonds see Table S5). These supramolecular layers further pack along the $\left[\begin{array}{lll}0 & 0 & 1\end{array}\right]$ direction of the unit cell. This packing arrangement is directed by an extensive $\mathrm{N}-\mathrm{H} \cdots \mathrm{O}$ and $\mathrm{O}-\mathrm{H} \cdots \mathrm{O}$ hydrogen bonding network, involving the amine and carboxylate groups of the aip ${ }^{2-}$ ligands, as well as the coordinated and uncoordinated water molecules, ultimately leading to a 3D supramolecular structure.

The utilization of co-ligands in the preparation of CPs or MOFs is a recognized strategy that is frequently applied to modify the material dimensionality or adjust its properties. Thus, the 1,10-phenatroline (phen) was used as co-ligand. A mixture of $\mathrm{H}_{2}$ aip, $\mathrm{Ca}(\mathrm{OH})_{2}$, and phen was added to a 1:1 water/methanol mixture and warmed to $323 \mathrm{~K}$ for $3 \mathrm{~h}$. After a few weeks, brown crystals were obtained with a $37 \%$ yield. The structure determined by SCXRD revealed a 1D metal-organic chain (Figure 4), formulated as [Ca(aip)(phen) $\left.\left(\mathrm{H}_{2} \mathrm{O}\right)_{2}\right] \cdot\left(\right.$ phen). $\left(\mathrm{H}_{2} \mathrm{O}\right)(4)$, which was previously published in 2010 [45]. Compound 4 was prepared with some differences relative to the original protocol: (i) The initial dissolution period of the reagents was neglected, (ii) $\mathrm{NH}_{3}$ was not added, and (iii) the crystals were obtained in the same crystallization period without the need to use a water bath at $323 \mathrm{~K}$. Therefore, this protocol is less energetically consuming and, in some degree, more environmentally friendly. 

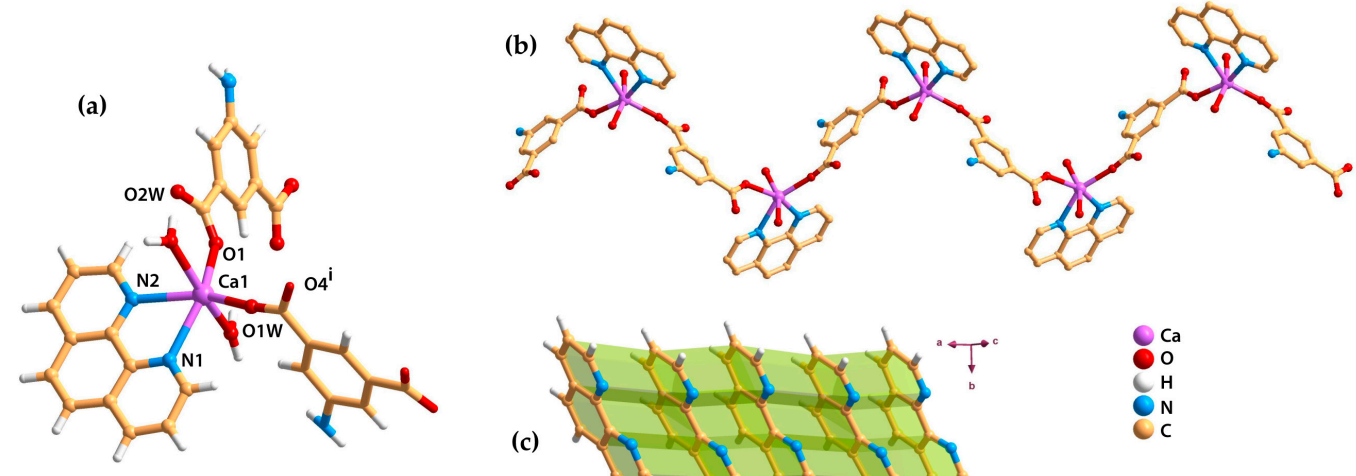

(c)
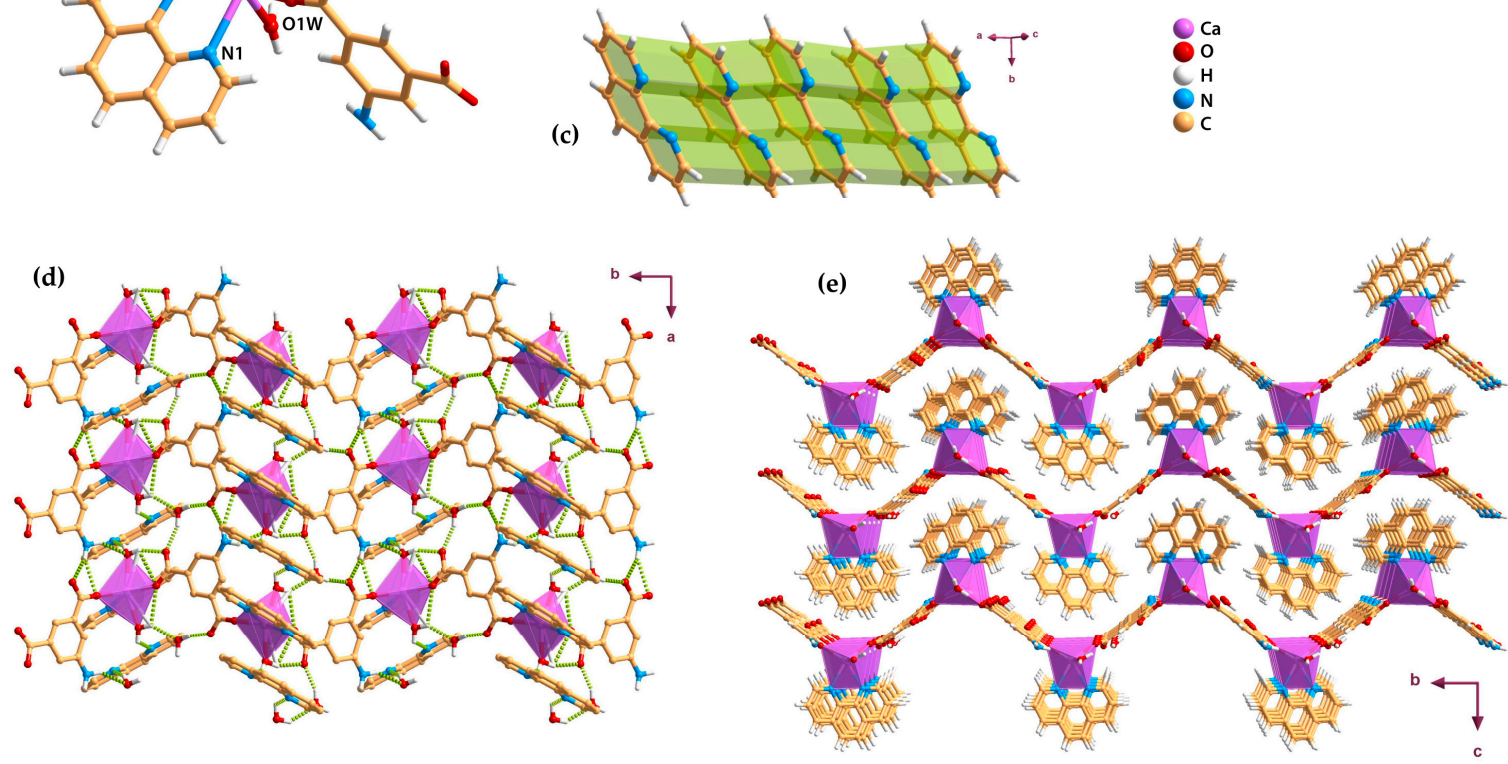

Figure 4. (a) Coordination environment for the Ca1 center in the crystal structure $\left[\mathrm{Ca}\right.$ (aip)(phen) $\left.\left(\mathrm{H}_{2} \mathrm{O}\right)_{2}\right] \cdot\left(\right.$ phen) $\cdot\left(\mathrm{H}_{2} \mathrm{O}\right)(4)$, with the labelling scheme for the atoms of the coordination sphere; (b) zig-zag 1D metal-organic chain; (c) $\pi \cdots \pi$ stacking between adjacent coordinated and uncoordinated phen molecules; (d) 2D supramolecular layer extended in the ab plan of the unit cell; and (e) extended packing viewed in the $\left[\begin{array}{lll}1 & 0 & 0\end{array}\right]$ direction of the unit cell.

It was confirmed that the asu of 4 is composed by one $\mathrm{Ca}^{2+}$, one aip ${ }^{2-}$ ligand, one coordinated phen, two coordinated water molecules, one uncoordinated phen, and one crystallization water molecule (Figure S4 in ESI). The $\mathrm{Ca}^{2+}$ center $\left\{\mathrm{CaO}_{4} \mathrm{~N}_{2}\right\}$ possesses a distorted octahedral geometry, with the Ca1-O distances ranging from 2.249 to $2.388 \AA$, and the Ca1-N distances from 2.501 to $2.534 \AA$ (Figure 4a; detailed information concerning the bond lengths and angles of the Ca1 coordination center is summarized in Table S7). The crystallographic-independent aip ${ }^{2-}$ ligand coordinates to two equivalent $\mathrm{Ca}^{2+}$ centers by one $\mathrm{O}$-atom of each carboxylate group, establishing a 1D zigzag metal-organic chain through a bridging mode (Figure $4 \mathrm{~b}$ ). Both coordinated and uncoordinated phen molecules are positioned face-to-face, which allows weak $\pi \cdots \pi$ interactions (Figure $4 \mathrm{c}$ ). Furthermore the occurrence of an extensive hydrogen bonding network $(\mathrm{C}-\mathrm{H} \cdots \mathrm{O}, \mathrm{O}-\mathrm{H} \cdots \mathrm{O}, \mathrm{N}-\mathrm{H} \cdots \mathrm{O}$ and $\mathrm{O}-\mathrm{H} \cdots \mathrm{N})$ between the 1D coordination chains leads to the formation of 2D supramolecular layers (Figure $4 \mathrm{~d}$; geometric details concerning all the types of hydrogen bonds are listed in Table S8), which are further extended into a 3D supramolecular arrangement through hydrogen bonds (Figure 4e).

The maintenance of the synthetic strategy used to prepare the previous metal-organic chain material, just replacing the $\mathrm{Ca}^{2+}$ metal center by $\mathrm{Ba}^{2+}$, was carried out, as an attempt to increase the dimensionality of the material. A mixture of $\mathrm{H}_{2}$ aip, $\mathrm{Ba}(\mathrm{OH})_{2}$, and phen was added one-by-one to hot water and maintained for $68 \mathrm{~h}$ at $323 \mathrm{~K}$ (hydrothermal reaction), and dark pink crystals suitable for $\mathrm{X}$-ray diffraction were obtained in a $15 \%$ yield (compound 5 ).

The crystal structure of 5 , formulated as $\left[\mathrm{Ba}_{2}(\text { aip })_{2}(\text { phen })_{2}\left(\mathrm{H}_{2} \mathrm{O}\right)_{7}\right] \cdot 2($ phen $) \cdot 2\left(\mathrm{H}_{2} \mathrm{O}\right)$, was unveiled in the triclinic space group $P 1$, and the asu revealed two crystallographic non-independent $\mathrm{Ba}^{2+}$ centers, two fully deprotonated ligands $\left(\right.$ aip $^{2-}$ ), two coordinated phen molecules, seven coordinated 
water molecules, two solvation water molecules, and two uncoordinated phen molecules (Figure S5a). The two $\mathrm{Ba}^{2+}$ centers (Ba1 and Ba2) are structurally distinct and share three bridging bonds by three O-atoms, imposing a distance from each other of $4.451 \AA$. Ba1 is octa-coordinated due to bonds with one carboxylate $\mathrm{O}$-atom of a aip ${ }^{2-}$ ligand, two $\mathrm{N}$-atoms from the co-ligand (phen), and four water molecules, $\left\{\mathrm{BaO}_{6} \mathrm{~N}_{2}\right\}$, while the $\mathrm{Ba} 2$ is a hepta-coordinated center, as consequence of the bonds to one carboxylate $\mathrm{O}$-atom of a aip ${ }^{2-}$ ligand, two $\mathrm{N}$-atoms from the co-ligand (phen), and three water molecules, $\left\{\mathrm{BaO}_{5} \mathrm{~N}_{2}\right\}$ (Figure 5). The Ba1-O and Ba1-N distances range from 2.726(2) to 3.017(4) $\AA$ and from 2.915(5) to 2.937(5) $\AA$, respectively, while the Ba2-O are between 2.823(2)-2.987(4) $\AA$, and Ba2-N distances from 2.855(4) to 2.956(5) $\AA$ (the bond distances and angles involving the two Ba coordination centers are listed in Table S9). The coordinated phen molecules in adjacent metal centers are disposed in opposite directions but parallel with respective neighboring uncoordinated phen molecules (Figure S5). This phen-phen arrangement leads to $\pi \cdots \pi$ stacking, which seems to be more effective for the phen molecules coordinated and closer to the $\mathrm{Ba} 2$ metal center since the two phen are equally positioned while those associated to Ba1 are slightly twisted from one another.

One of the crystallographic-independent aip ${ }^{2-}$ ligand coordinates to three $\mathrm{Ba}^{2+}$ centers (two chelating bidentate interaction and a simple bond to carboxylate $O$-atoms) while the other only coordinates to one $\mathrm{Ba}^{2+}$ via a carboxylate $\mathrm{O}$-atoms (see Figure $\mathrm{S} 5 \mathrm{~b}$ ). This coordination mode between the $\mathrm{Ba}^{2+}$ metal centers and the organic ligands leads to the formation of a 1D metal-organic ladder chains (1D CP) running along the $a$-axis of the unit cell (Figure $5 \mathrm{~b}$ ). The supramolecular layers

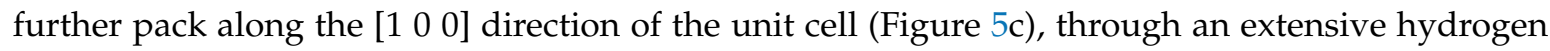
bonding network of type $\mathrm{N}-\mathrm{H} \cdots \mathrm{O}, \mathrm{O}-\mathrm{H} \cdots \mathrm{N}$, and $\mathrm{O}-\mathrm{H} \cdots \mathrm{O}$, involving the amine and carboxylate groups of the aip ${ }^{2-}$ ligands, the $N$-atoms of the phen coordinated molecules as well as the coordinated and uncoordinated water and phen molecules, ultimately leading to a 3D supramolecular structure (detailed information about geometry of the hydrogen bonds can be found in Table S10).
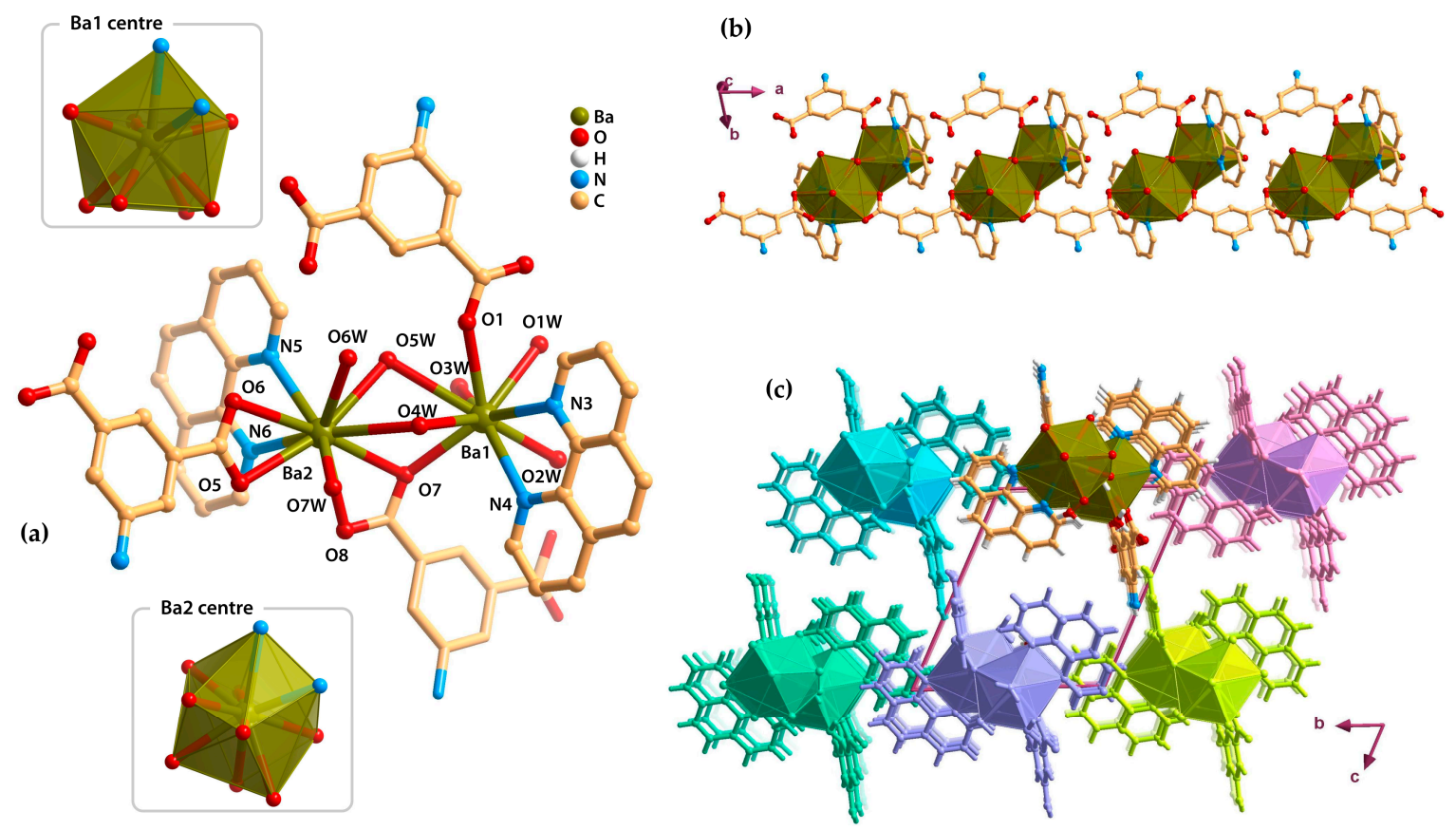

Figure 5. Selected details in the structure of $\left[\mathrm{Ba}_{2}(\text { aip })_{2}(\text { phen })_{2}\left(\mathrm{H}_{2} \mathrm{O}\right)_{7}\right] \cdot 2($ phen $) \cdot 2\left(\mathrm{H}_{2} \mathrm{O}\right)(5)$ : (a) partial asu with the labelling scheme for all the atoms of the coordination sphere and the coordination environment of $\mathrm{Ba} 1$ and $\mathrm{Ba} 2$ centers (also shown as separated polyhedral representation); (b) 1D metal-organic chain showing a ladder arrangement and running along the $a$-axis of the unit cell; (c) extended packing arrangement viewed in the $\left[\begin{array}{lll}0 & 1 & 1\end{array}\right]$ direction of the unit cell (the 1D coordination chains are drawn at different colors). 


\subsection{Metal-Organic Layers (2D)}

The complex 6, $\left[\mathrm{Ba}(\mathrm{aip})\left(\mathrm{H}_{2} \mathrm{O}\right)\right]$, that revealed a metal-organic layered structure $(2 \mathrm{D} \mathrm{CP})$, was prepared using a much more sustainable method than that reported by reported by Wu and co-workers [46]. Herein, the application of conventional heating (only at $50^{\circ} \mathrm{C}$ ) followed by self-assembly originated the desired materials, in contrast with the solvothermal process (at $150{ }^{\circ} \mathrm{C}$ ) previously employed. The crystal structure of this compound was determined in the triclinic space group $P-1$ (see more details in the experimental section), with the respective asu composed of only one $\mathrm{Ba}^{2+}$ center, one deprotonated ligand ( aip $^{2-}$ ), and one coordinated water molecule (Figure S6a). The Ba ${ }^{2+}$ center is coordinated by six carboxylate $O$-atoms belonging to four symmetry-related aip ${ }^{2-}$ anionic ligands, an $\mathrm{N}$-atom from another anionic organic ligand, and one water molecule, $\left\{\mathrm{BaO}_{7} \mathrm{~N}\right\}$ (Figure 6). The geometry of this eight-coordinated center resembles a dodecahedron, highly distorted, with $\mathrm{Ba}-\mathrm{O}$ distances ranging from 2.6802 to $2.8815 \AA$, and the Ba-N distance slightly longer [2.9255 $\mathrm{A}$ ]. The evident distortion of the Ba coordination center is supported by the values of the $\mathrm{O}(\mathrm{N})-\mathrm{Ba}-\mathrm{O}(\mathrm{N})$ internal angles: The cis angles are found between 45.82 to $126.71^{\circ}$ while the trans angles range from 143.23 to $167.88^{\circ}$ (for details about these bond lengths and angles, see Table S11).

(a)
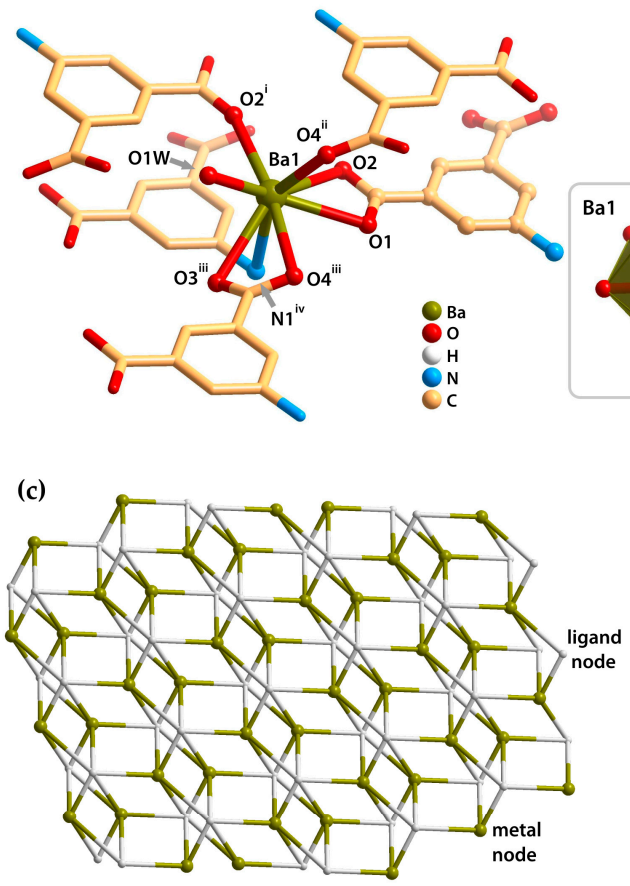

(b)

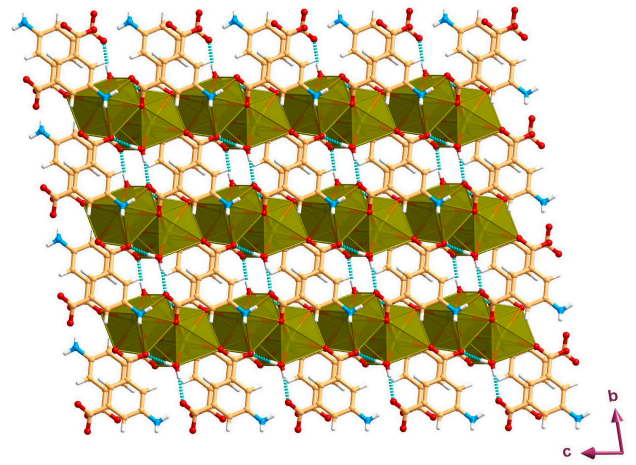

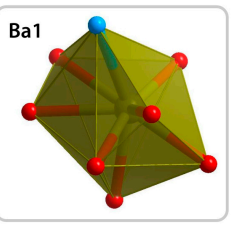

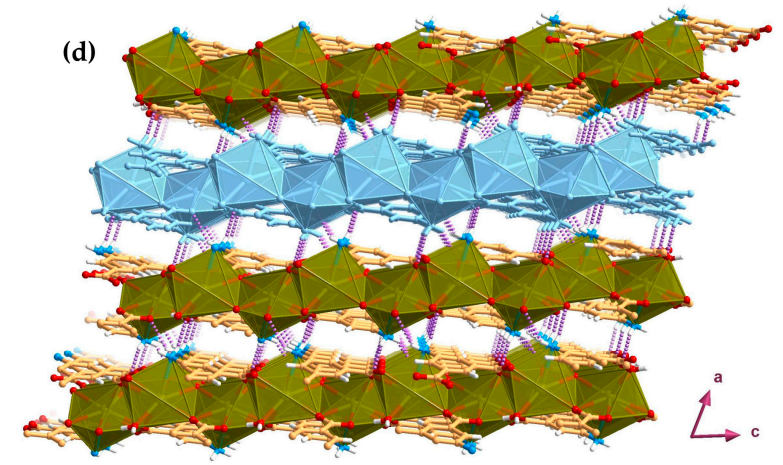

Figure 6. Selected details of the crystal structure of $\left[\mathrm{Ba}(\mathrm{aip})\left(\mathrm{H}_{2} \mathrm{O}\right)\right](\mathbf{6})$ : (a) full coordination environment of Ba1 center and polyhedral representation of highly distorted dodecahedral geometry; (b) 2D metal-organic layer extended in the $\left[\begin{array}{lll}1 & 0 & 0\end{array}\right]$ direction of the unit cell; (c) the topology representation of the 2D metal-organic layer; (d) global packing arrangement viewed in the $\left[\begin{array}{ll}0 & 1\end{array}\right]$ ] direction of the unit cell, where one coordination layer is highlighted in the blue color.

The aip ${ }^{2-}$ ligands coordinate to five $\mathrm{Ba}^{2+}$ centers by the carboxylate $O$-atoms and the amino $\mathrm{N}$-atom (see Figure S6b), leading to the formation of 2D metal-organic layers extended in the [ $\left[\begin{array}{lll}1 & 0 & 0\end{array}\right]$ direction of the unit cell (Figure $6 \mathrm{~b}$ ). The adjacent layers close pack along the $a$-axis of the unit cell. This packing arrangement is reinforced by an extensive network of strong hydrogen bonds $(\mathrm{N}-\mathrm{H} \cdots \mathrm{O}$ and $\mathrm{O}-\mathrm{H} \cdots \mathrm{O})$, involving the amine and carboxylate groups of the aip ${ }^{2-}$ ligands, as well as the coordinated water molecule, originating a 3D supramolecular structure (Figure 6c; see Table S12 in Supplementary Materials about the hydrogen bonds' geometry). 


\subsection{Vibrational Spectroscopy and Thermal Stability}

The vibrational spectroscopy was studied using FTIR-ATR and the results obtained for the compounds 1-6 are shown in Figure 7 (selected region from 1800 to $400 \mathrm{~cm}^{-1}$ ). The spectra of all the compounds reveal characteristic bands in the region from 3600 to $3000 \mathrm{~cm}^{-1}$ related to the O-H and N-H stretching, with higher expression/intensity on the hydrated materials (not shown). Furthermore, the materials present a large number of bands in the $1700-1300 \mathrm{~cm}^{-1}$ region that can be associated to the stretching of $\mathrm{C}-\mathrm{H}, \mathrm{C}=\mathrm{C}, \mathrm{C}-\mathrm{O}$, and $\mathrm{N}-\mathrm{O}$ and to the bending of $\mathrm{N}-\mathrm{H}$ and $\mathrm{C}-\mathrm{O}$. On the other hand, the multiple bands presented in the $900-600 \mathrm{~cm}^{-1}$ region are related to $\mathrm{C}=\mathrm{C}$ and $\mathrm{C}-\mathrm{H}$ bending.

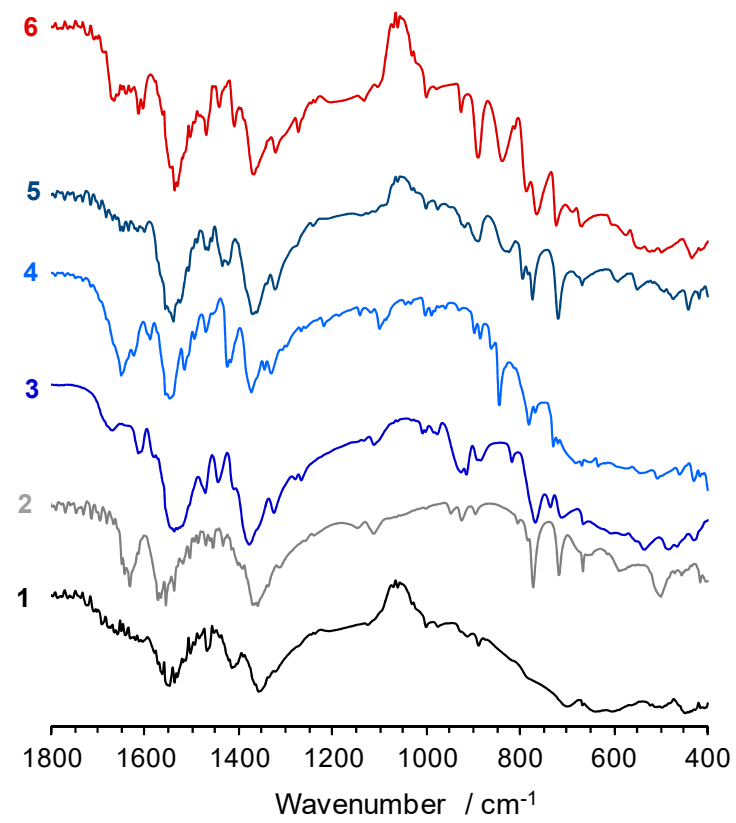

Figure 7. FTIR absorption spectra of the compounds 1-6, showed in the wavenumber region between 1800 and $400 \mathrm{~cm}^{-1}$.

The thermal stability of the materials was studied using thermogravometric analysis TGA (Figure 8). From the TGA curves of discrete complexes $\mathbf{1}$ and $\mathbf{2}$ (black and grey line, respectively), it is possible to verify that the main difference is the higher decrease (slope) of the first mass loss for $\mathbf{1}$, which is due to the large difference in water content (lattice and coordinated) in the $\mathrm{Mg}$ (II) complexes ( 26 vs. 6 water molecules in $\mathbf{1}$ and 2, respectively). Another difference observed relates to the thermal stability of the complexes: $\mathbf{1}$ seems to be slightly more stable than $\mathbf{2}$ (stable up to $\approx 490{ }^{\circ} \mathrm{C}$ for $\mathbf{1}$ vs. $\approx 390{ }^{\circ} \mathrm{C}$ for 2$)$. This fact can be associated to the intermolecular interaction networks $(\pi \cdots \pi \mathrm{stacking}$ and H-bonds), which is more expressive in the extended structure of the complex 1. For material 3, two mass losses are observed, the first one $(\approx 25 \%$, calculated value of $20 \%)$ corresponding to the loss of the three water molecules (two coordinated and one uncoordinated) and the second corresponding to the material destruction at $\approx 570{ }^{\circ} \mathrm{C}$. On the other hand, material 4 presents several mass losses; these losses can be attributed to the loss of uncoordinated and coordinated water $(\approx 7 \%$, calculated value of $8 \%$ ) and phen ( $\approx 37 \%$, calculated value of $30 \%$, and $68 \%$, calculated value of $63 \%$, respectively) molecules up to the material destruction at $\approx 500{ }^{\circ} \mathrm{C}$. For material 5 , the TGA curve profile presents a series of mass losses (Figure 8 , green line). The first two mass losses correspond to the expulsion of the lattice and coordination water molecules $(\approx 9 \%$, calculated value of $8 \%$ ) while the following correspond to the release of the phen organic ligands followed by the loss of the aip ${ }^{2-}$ ligands, leading to a steady destruction of the material around $480{ }^{\circ} \mathrm{C}$. The thermal stability of 6 was also studied and revealed that the structure is stable up to $430{ }^{\circ} \mathrm{C}$ (Figure 8 , wine line). The first mass loss of approximately $7 \%$ corresponds to the loss of the lattice water (calculated value of $5 \%$ ) and the second 
one, $\approx 42 \%$ (expected value of $41 \%$ ), corresponds to the loss of the ligand aip ${ }^{2-}$ and the corresponding destruction of the coordination polymer (CP). Most of the materials, with the exception of $\mathbf{4}$ and $\mathbf{5}$, are stable up to at least $450{ }^{\circ} \mathrm{C}$ and their stability can be correlated to the corresponding structures and intermolecular interactions.

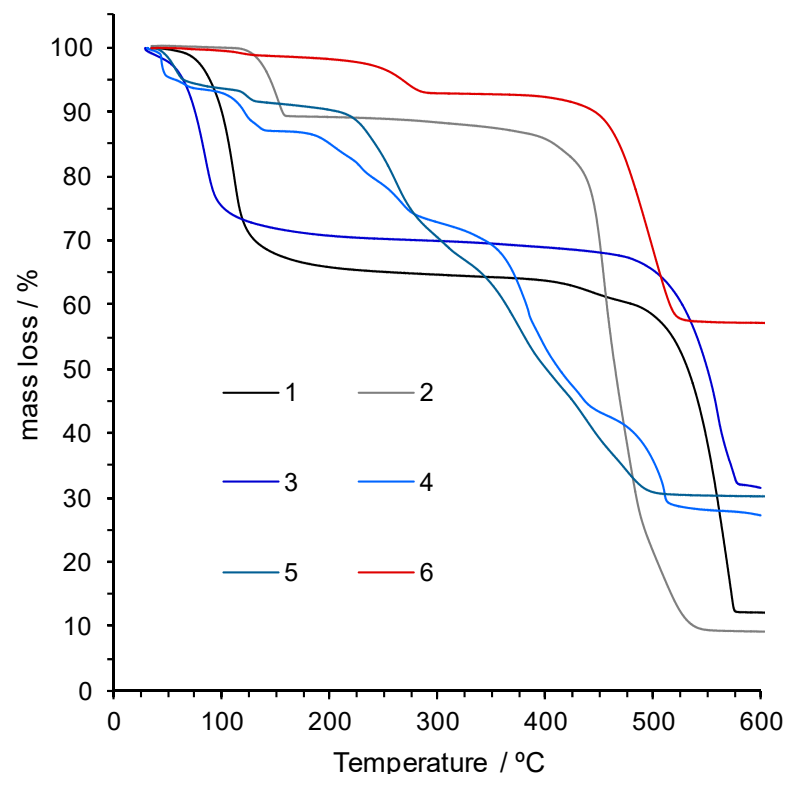

Figure 8. TGA profiles of the materials 1-6 between 30 and $600{ }^{\circ} \mathrm{C}$ with a heat rate of $5{ }^{\circ} \mathrm{C} / \mathrm{min}$ in a $20 \mathrm{~cm}^{3} / \mathrm{min}$ air flow stream.

\section{Experimental Section}

\subsection{Materials and Methods}

Reagents and solvents were purchased as reagent-grade products and used without further purification unless otherwise stated. Microwave-assisted reactions were carried out in a CEM Discovery Labmate circular single-mode cavity instrument ( $300 \mathrm{~W}$ max magnetron power output) from CEM Corporation. Microanalyses were acquired by Unidad De Análisis Elemental of Santiago de Compostela. FT-IR spectra were obtained neat with a FT-IR Perkin Elmer Spectrum BX with an attenuated total reflectance (ATR) accessory.

\subsection{Preparation of Materials}

$\left[\mathrm{Mg}\left(\mathrm{H}_{2} \mathrm{O}\right)_{6}\right] \cdot\left[\mathrm{Mg}_{2}(\right.$ Haip $\left.)\left(\mathrm{H}_{2} \mathrm{O}\right)_{10}\right] \cdot 3$ (Haip).(aip)·10 $\left(\mathrm{H}_{2} \mathrm{O}\right)(\mathbf{1}) \cdot \mathrm{H}_{2}$ aip $(0.25 \mathrm{~g}, 1.38 \mathrm{mmol})$ and $\mathrm{Mg}(\mathrm{OH})_{2}$ $(0.08 \mathrm{~g}, 1.37 \mathrm{mmol})$ were added to hot water $(5 \mathrm{~mL})$. The mixture was maintained for $65 \mathrm{~h}$ at $323 \mathrm{~K}$, and after cooling was filtered and placed on a 30-mL glass vial. Red/brown crystals were obtained after a few weeks in $12 \%$ yield (243 mg). Elemental analysis (\%) calcd. for $\mathrm{C}_{40} \mathrm{H}_{81} \mathrm{Mg}_{3} \mathrm{~N}_{5} \mathrm{O}_{46}(1441.03 \mathrm{~g} / \mathrm{mol})$ : C 33.34, H 5.67, N 4.86; found: C 33.33, H 5.92, N 4.43; Selected FT-IR (solid phase, $v / \mathrm{cm}^{-1}$ ): $3200 \mathrm{~m}$, 2944 w, 2842 w, 2362 m, 2342 m, 1556 s, 1466 w, 1412 m, 1354 s, 916 w, 890 w, 700 w.

[Mg(aip)(phen) $\left.\left(\mathrm{H}_{2} \mathrm{O}\right)_{2}\right] \cdot\left(\mathrm{H}_{2} \mathrm{O}\right)$ (2). H2aip (1.0 equiv., $\left.1.00 \mathrm{mmol}, 182.1 \mathrm{mg}\right), \mathrm{Mg}(\mathrm{OH}) 2$ (1.34 equiv., $1.34 \mathrm{mmol}, 78.3 \mathrm{mg})$ and 1,10-phen ( 0.62 equiv., $0.62 \mathrm{mmol}, 122.0 \mathrm{mg})$ were added to a 1:1 mixture of $\mathrm{H}_{2} \mathrm{O}$ /acetone $(10 \mathrm{~mL})$. The mixture was transferred to a 23-mL Teflon-lined reactor. The reactor was sealed and heated to $403 \mathrm{~K}$ for $72 \mathrm{~h}$. After cooling, pink/brown crystals were collected by filtration and dried at $323 \mathrm{~K}$ for $5 \mathrm{~h}$ and a $45 \%$ yield was obtained $\left(385.3 \mathrm{mg}\right.$ ). Selected FT-IR (solid phase, $v / \mathrm{cm}^{-1}$ ): 3242 m, 2355 m, 1668 w, 1610 m, 1540 s, 1444 m, 1472 m, 1375 s, 1006 w, 980 w, 922 m, 770 m, 709 m.

[Ca(aip) $\left.\left(\mathrm{H}_{2} \mathrm{O}\right)_{2}\right] \cdot\left(\mathrm{H}_{2} \mathrm{O}\right)(3)$. A mixture of $\mathrm{H}_{2}$ aip $(0.50 \mathrm{~g}, 2.76 \mathrm{mmol})$ and $\mathrm{Ca}(\mathrm{OH})_{2}(0.21 \mathrm{~g}, 2.83 \mathrm{mmol})$ was prepared in water $(10 \mathrm{~mL})$ and heated at $323 \mathrm{~K}$ during $64 \mathrm{~h}$. The mixture was filtered, and the 
filtrate was transferred to a 20-mL glass vial and kept at room temperature for several days, after which a clear pink crystalline solid began to form on the vial walls, in $28 \%$ yield (208 $\mathrm{mg}$ ). Elemental analysis (\%) calcd. for $\mathrm{C}_{8} \mathrm{H}_{11} \mathrm{CaNO}_{7}(273.26 \mathrm{~g} / \mathrm{mol})$ : C 35.16, $\mathrm{H} 4.06, \mathrm{~N} 5.13$; found: C 35.18, H 4.05, N 5.53. Selected FT-IR (solid phase, v/cm ${ }^{-1}$ ): 3385 s, 3313 w, 3203 w, 1556 m, $1541 \mathrm{~m}, 1516$ s, $1471 \mathrm{~s}, 1425 \mathrm{~m}$, 1375 m, 1139 s, 998 s, 845 m, 780 m, 724 m, 636 s.

[Ca(aip)(phen) $\left.\left(\mathrm{H}_{2} \mathrm{O}\right)_{2}\right] \cdot\left(\right.$ phen) $\left(\mathrm{H}_{2} \mathrm{O}\right)(4)$. H2aip (1.0 equiv., $\left.1.00 \mathrm{mmol}, 97.8 \mathrm{mg}\right), \mathrm{Ca}(\mathrm{OH})_{2}(1.0$ equiv., $0.57 \mathrm{mmol}, 42.5 \mathrm{mg}$ ) and water $(5 \mathrm{~mL})$ were placed in a $10-\mathrm{mL}$ reaction vessel, which was then closed and placed in the cavity of a CEM microwave reactor. The reaction vessel was irradiated at $383 \mathrm{~K}$ for $4 \mathrm{~h}$. After cooling, the mixture was filtered and transferred to a glass vessel and was allowed to stand for $24 \mathrm{~h}$ after which a pale pink crystalline solid began to deposit on the vessel bottom. Single crystals suitable for X-ray diffraction were collected with $83 \%$ yield $(138.2 \mathrm{mg}$ ). Selected FT-IR (solid phase, $v / \mathrm{cm}^{-1}$ ): $3250 \mathrm{w}, 1644 \mathrm{~m}, 1610 \mathrm{~s}, 1538 \mathrm{~m}, 1470 \mathrm{~s}, 1444 \mathrm{~s}, 1390 \mathrm{~m}, 1324 \mathrm{~s}, 1276 \mathrm{~s}, 892 \mathrm{~s}, 780 \mathrm{~s}, 734 \mathrm{~s}$.

$\left[\mathrm{Ba}_{2}(\text { aip })_{2}(\text { phen })_{2}\left(\mathrm{H}_{2} \mathrm{O}\right)_{7}\right] \cdot 2($ phen $) \cdot 2\left(\mathrm{H}_{2} \mathrm{O}\right)(5)$. A conventional heating procedure was utilized in the preparation of the material: $\mathrm{H}_{2}$ aip (1.0 equiv., $\left.2.76 \mathrm{mmol}, 500.2 \mathrm{mg}\right), \mathrm{Ba}(\mathrm{OH})_{2}(0.90$ equiv., $2.48 \mathrm{mmol}$, $425.0 \mathrm{mg}$ ) and 1,10-phen ( 0.60 equiv., $1.66 \mathrm{mmol}, 338.2 \mathrm{mg})$ were added one-by-one to hot water $(10 \mathrm{~mL})$. The mixture was maintained at $323 \mathrm{~K}$ for $68 \mathrm{~h}$. After cooling, the mixture was filtered and the solution concentrated in a rotavapor until some precipitation occurred. The mixture was then transferred to a 30-mL glass vessel, and chloroform and methanol were added. Dark pink crystals suitable for X-ray diffraction were obtained after a month with $15 \%$ yield $\left(371.3 \mathrm{mg}\right.$ ). Selected FT-IR (solid phase, $v / \mathrm{cm}^{-1}$ ): 3376 m, 3314 m, 2941 w, 2358 w, 2338 w, 1542 s, 1469 m, 1424 m, 1374 s, 1320 m, 894w, 826 w, 785 m, $774 \mathrm{~m}, 719 \mathrm{~m}$

[Ba(aip) $\left.\left(\mathrm{H}_{2} \mathrm{O}\right)\right]$ (6). $\mathrm{H}_{2}$ aip $(0.25 \mathrm{~g}, 1.38 \mathrm{mmol}), \mathrm{Ba}(\mathrm{OH})_{2}(0.21 \mathrm{~g}, 1.22 \mathrm{mmol})$ were added to hot water $(5 \mathrm{~mL})$. The mixture was maintained for $65 \mathrm{~h}$ at $323 \mathrm{~K}$. After cooling, the mixture was filtered and the solution was kept at room temperature for a month. Dark pink crystals were collected and dried in air with $59 \%$ yield (242 mg). Elemental analysis (\%) calcd. for $\mathrm{C}_{8} \mathrm{H}_{7} \mathrm{BaNO}_{5}(334.47 \mathrm{~g} / \mathrm{mol}): \mathrm{C} 28.73, \mathrm{H} 2.11$, N 4.19; found: C 28.70, H 2.14, N 4.09. Selected FT-IR (solid phase, $v / \mathrm{cm}^{-1}$ ): $2944 \mathrm{~m}, 2367 \mathrm{~m}, 2346 \mathrm{w}$, $1554 \mathrm{~m}, 1436 \mathrm{w}, 1353 \mathrm{~m}, 1320 \mathrm{~m}, 772 \mathrm{w}, 718 \mathrm{w}$.

\subsection{X-ray Diffraction}

Crystalline material of complexes 1-6 were manually harvested from the respective crystallization vial, immersed in highly viscous inert oil, and a suitable single-crystal of each complex was mounted on a cryoloop or thin glass fiber [47]. Data were collected at 150 or $180 \mathrm{~K}$ on a Bruker X8 APEX II charge-coupled device (CCD) area-detector diffractometer (Mo $\mathrm{K}_{\alpha}$ graphite-monochromated radiation, $\lambda=0.71073 \AA$ ), controlled by the APEX2 software package [48]. Images were processed using the software package SAINT+ [49], and data were corrected for absorption by the multi-scan method implemented in SADABS [50]. The structures were solved by direct methods SHELXS-97 [51,52], permitting the direct location of most of the heaviest atoms, and the remaining non-hydrogen atoms were located from difference Fourier maps calculated from successive full-matrix least squares refinement cycles on $F^{2}$ using SHELXL-97 [51,53].

All non-hydrogen atoms were successfully refined using anisotropic displacement parameters, and hydrogen atoms attached to carbon were set at idealized positions, and included in subsequent refinement cycles in riding-motion approximation with isotropic thermal displacements parameters $\left(U_{i s o}\right)$ fixed at $1.2 \times U_{e q}$ of the carbon atom to which they are connected. In general, hydrogen atoms associated with the water molecules and nitrogen atoms were located in difference Fourier maps, the corresponding $\mathrm{N}-\mathrm{H}, \mathrm{O}-\mathrm{H}$, and $\mathrm{H} \cdots \mathrm{H}$ distances were fixed at appropriated values, and included in subsequent refinement cycles in riding-motion approximation, with isotropic thermal displacements parameters $\left(U_{\text {iso }}\right)$ fixed at $1.5 \times U_{e q}$ of the respective parent atom. Table 2 summarizes the acquisitions data and structure refinements details for complexes 1-6. 
Table 2. Crystal data collection and refinement details for $\left[\mathrm{Mg}\left(\mathrm{H}_{2} \mathrm{O}\right)_{6}\right] \cdot\left[\mathrm{Mg}_{2}(\right.$ Haip $\left.)\left(\mathrm{H}_{2} \mathrm{O}\right)_{10}\right] \cdot($ Haip $) \cdot 3($ aip $) \cdot 10\left(\mathrm{H}_{2} \mathrm{O}\right)(\mathbf{1})$, $\left[\mathrm{Mg}(\right.$ aip $)($ phen $\left.)\left(\mathrm{H}_{2} \mathrm{O}\right)_{2}\right] \cdot\left(\mathrm{H}_{2} \mathrm{O}\right)(\mathbf{2})$, $\left[\mathrm{Ca}(\right.$ aip $\left.)\left(\mathrm{H}_{2} \mathrm{O}\right)_{2}\right] \cdot\left(\mathrm{H}_{2} \mathrm{O}\right)(3)$, [Ca(aip)(phen) $\left.\left(\mathrm{H}_{2} \mathrm{O}\right)_{2}\right] \cdot\left(\right.$ phen). $\left(\mathrm{H}_{2} \mathrm{O}\right)(4),\left[\mathrm{Ba}_{2}(\text { aip })_{2}(\text { phen })_{2}\left(\mathrm{H}_{2} \mathrm{O}\right)_{7}\right] \cdot 2\left(\right.$ phen) $\cdot 2\left(\mathrm{H}_{2} \mathrm{O}\right)(5)$, and $\left[\mathrm{Ba}(\right.$ aip $\left.)\left(\mathrm{H}_{2} \mathrm{O}\right)\right](\mathbf{6})$.

\begin{tabular}{|c|c|c|c|c|c|c|}
\hline & 1 & 2 & 3 & 4 & 5 & 6 \\
\hline Formula & $\mathrm{C}_{40} \mathrm{H}_{81} \mathrm{Mg}_{3} \mathrm{~N}_{5} \mathrm{O}_{46}$ & $\mathrm{C}_{40} \mathrm{H}_{36} \mathrm{Mg}_{2} \mathrm{~N}_{6} \mathrm{O}_{13}$ & $\mathrm{C}_{8} \mathrm{H}_{11} \mathrm{CaNO}_{7}$ & $\mathrm{C}_{32} \mathrm{H}_{27} \mathrm{CaN}_{5} \mathrm{O}_{7}$ & $\mathrm{C}_{64} \mathrm{H}_{60} \mathrm{Ba}_{2} \mathrm{~N}_{10} \mathrm{O}_{17}$ & $\mathrm{C}_{8} \mathrm{H}_{7} \mathrm{BaNO}_{5}$ \\
\hline$M r$ & 1441.03 & 857.37 & 273.26 & 633.67 & 1515.90 & 334.49 \\
\hline Crystal morphology & orange/prism & Orange/plate & orange/prism & orange/prism & orange/prism & orange/prism \\
\hline Crystal system & Monoclinic & Monoclinic & Triclinic & Monoclinic & Triclinic & Triclinic \\
\hline Space group & $P 2_{1} / \mathrm{c}$ & $P 2_{1} / \mathrm{c}$ & $P-1$ & $P 2_{1}$ & $P 1$ & $P-1$ \\
\hline$a / \AA$ & $17.6784(10)$ & $11.7432(9)$ & $8.1375(9)$ & $8.2128(14)$ & $10.9458(4)$ & $7.76210(10)$ \\
\hline$b / \AA$ & $29.6003(18)$ & $47.433(3)$ & $10.2726(10)$ & $17.373(3)$ & $11.9419(4)$ & $7.96520(10)$ \\
\hline$\alpha /^{\circ}$ & 90 & 90 & $74.135(5)$ & 90 & $64.1780(10)$ & $79.6180(10)$ \\
\hline$\beta /^{\circ}$ & $98.049(4)$ & $97.143(4)$ & $79.343(5)$ & $93.105(10)$ & $79.870(2)$ & $65.5740(10)$ \\
\hline$\gamma /^{\circ}$ & 90 & 90 & $84.520(5)$ & 90 & $77.1790(10)$ & $83.5750(10)$ \\
\hline Volume $/ \AA^{3}$ & $6069.0(6)$ & $7698.9(10)$ & $1053.19(19)$ & $1442.8(5)$ & $1532.06(10)$ & $461.483(10)$ \\
\hline Z & 4 & 8 & 4 & 2 & 1 & 2 \\
\hline$\rho_{\text {calc }} / \mathrm{g} \mathrm{cm}^{-3}$ & 1.577 & 1.479 & 1.723 & 1.459 & 1.643 & 2.407 \\
\hline$F(000)$ & 3040 & 3568 & 568 & 660 & 762 & 316 \\
\hline$\mu / \mathrm{mm}^{-1}$ & 0.171 & 0.141 & 0.621 & 0.277 & 1.359 & 4.303 \\
\hline$\theta$ range $/^{\circ}$ & $3.73-25.68$ & $3.65-23.26$ & $3.67-25.03$ & $3.90-25.02$ & $3.68-27.48$ & $3.67-27.46$ \\
\hline Independent relections & $11,485\left(R_{\text {int }}=0.1469\right)$ & $10,997\left(R_{\text {int }}=0.0930\right)$ & $3680\left(R_{\text {int }}=0.0294\right)$ & $5042\left(R_{\text {int }}=0.0703\right)$ & $13,072\left(R_{\text {int }}=0.0330\right)$ & $2099\left(R_{\text {int }}=0.0225\right)$ \\
\hline Parameters/Restraints & $1045 / 110$ & $1178 / 45$ & $355 / 20$ & $430 / 13$ & $904 / 36$ & $148 / 5$ \\
\hline Final $R$ indices $[I>2 \sigma(I)]$ & $\begin{array}{c}R_{1}=0.0793 \\
w R_{2}=0.1939\end{array}$ & $\begin{aligned} R_{1} & =0.108 \\
w R_{2} & =0.2839\end{aligned}$ & $\begin{array}{c}R_{1}=0.0292 \\
w R_{2}=0.0806\end{array}$ & $\begin{array}{c}R_{1}=0.0648 \\
w R_{2}=0.1404\end{array}$ & $\begin{array}{c}R_{1}=0.0296 \\
w R_{2}=0.0580\end{array}$ & $\begin{array}{c}R_{1}=0.0152 \\
w R_{2}=0.0316\end{array}$ \\
\hline Final $R$ indices (all data) & $\begin{array}{c}R_{1}=0.1603 \\
w R_{2}=0.2399\end{array}$ & $\begin{array}{c}R_{1}=0.1583 \\
w R_{2}=0.3209\end{array}$ & $\begin{array}{c}R_{1}=0.0418 \\
w R_{2}=0.0899\end{array}$ & $\begin{array}{c}R_{1}=0.0918 \\
w R_{2}=0.1554\end{array}$ & $\begin{array}{c}R_{1}=0.0330 \\
w R_{2}=0.0597\end{array}$ & $\begin{array}{c}R_{1}=0.0163 \\
w R_{2}=0.0321\end{array}$ \\
\hline $\begin{array}{l}\text { Min. and max. Residual } \\
\text { electr. density/e } \AA^{3}\end{array}$ & 0.9864 and -0.9748 & 0.890 and -1.099 & 0.352 and -0.266 & 1.211 and -0.343 & 0.845 and -0.410 & 0.454 and -0.420 \\
\hline Deposition code & CCDC-1981181 & CCDC-1981183 & CCDC-1981178 & CCDC-1981179 & CCDC-1981182 & CCDC-1981180 \\
\hline
\end{tabular}




\section{Concluding Remarks}

The application of distinct synthetic protocols, namely conventional heating and hydrothermal/solvothermal synthesis and selected experiments, allowed the preparation of six crystalline metal-organic materials based on alkaline earth (AE) metal ions and $\mathrm{H}_{2}$ aip. Their solid-state structures were unequivocally determined by single-crystal XRD, confirming the formation of coordination materials with distinct topologies and dimensionalities: Discrete complexes (0D), metal-organic chains (1D), and metal-organic layers (2D). The use of $\mathrm{Mg}^{2+}$ as the metal center originated the discrete complexes $\mathbf{1}$ and 2, formulated as $\left[\mathrm{Mg}\left(\mathrm{H}_{2} \mathrm{O}\right)_{6}\right] \cdot\left[\mathrm{Mg}_{2}(\right.$ Haip $\left.)\left(\mathrm{H}_{2} \mathrm{O}\right)_{10}\right] \cdot\left(\right.$ Haip) $\cdot 3$ (aip) $\cdot 10\left(\mathrm{H}_{2} \mathrm{O}\right)$ and $\left[\mathrm{Mg}(\right.$ aip $)($ phen $\left.)\left(\mathrm{H}_{2} \mathrm{O}\right)_{2}\right] \cdot\left(\mathrm{H}_{2} \mathrm{O}\right)$, respectively. The two materials prepared with $\mathrm{Ca}^{2+}$, $\left[\mathrm{Ca}(\right.$ aip $\left.)\left(\mathrm{H}_{2} \mathrm{O}\right)_{2}\right] \cdot\left(\mathrm{H}_{2} \mathrm{O}\right)(3)$, and $\left[\mathrm{Ca}(\right.$ aip $)($ phen $\left.)\left(\mathrm{H}_{2} \mathrm{O}\right)_{2}\right] \cdot($ phen $) \cdot\left(\mathrm{H}_{2} \mathrm{O}\right)(4)$ revealed $1 \mathrm{D}$ coordination polymeric structures. Interestingly, the $\mathrm{Ba}^{2+}$-based materials showed distinct coordination polymer dimensionalities: While 5, $\left[\mathrm{Ba}_{2}(\text { aip })_{2}(\text { phen })_{2}\left(\mathrm{H}_{2} \mathrm{O}\right)_{7}\right] \cdot 2($ phen $) \cdot 2\left(\mathrm{H}_{2} \mathrm{O}\right)$, is a $1 \mathrm{D}$ coordination chain, 6, $\left[\mathrm{Ba}(\right.$ aip $\left.)\left(\mathrm{H}_{2} \mathrm{O}\right)\right]$, is a $2 \mathrm{D}$ coordination layer. All six materials comprise coordinated and/or uncoordinated water molecules, which are engaged in extensive networks of hydrogen bonds. The "hydration level" of the materials seems to influence their thermal stability, however, some of these materials were found to be stable up to $450{ }^{\circ} \mathrm{C}$. Furthermore, the structures reported reveal the importance of the coordination behaviors of 5-aminosiophthate, which is useful for developing functional coordination network materials that take advantage of the amino functionality by post-synthetic modifications. Actually, this research work has been extended to new generations of functional MOF materials applied as photoluminescent sensors and oxidative catalysts.

Supplementary Materials: Several additional figures related with the crystal structures of all the materials (Figures S1-S6), as well as tables containing geometrical information concerning the metal coordination centers (bond distances and internal angles; Tables S1, S3, S5, S7, S9 and S11) and tables with geometrical details of the strong hydrogen bonds (Tables S2, S4, S6, S8, S10 and S12) are available online.

Author Contributions: L.C.-S. idealized and designed the experiments; C.Q. performed most of the experiments; L.C.-S. and C.Q. wrote the paper; A.M.G.S. and B.d.C. participated in the scientific discussion. All authors have read and agreed to the published version of the manuscript.

Funding: Fundação para a Ciência e a Tecnologia/Ministério da Ciência, Tecnologia e Ensino Superior (FCT/MCTES) by the financial support using national funds (OE) to the REQUIMTE-LAQV (strategic project Ref. UID/QUI/50006/2019).

Acknowledgments: LCS and AMGS thanks the FCT/MCTES by the work contract in the scope of the framework contract foreseen in the numbers 4, 5 and 6 of the article 23, of the Decree-Law 57/2016, of August 29, changed by Law 57/2017, of July 19.

Conflicts of Interest: The authors declare no conflict of interest.

\section{References}

1. Cao, R.; Lu, J.; Batten, S. Copper 5-sulfoisophthalato quasi-planar squares in coordination polymers modulated by alkaline-earth metals: A way to molecular squares? CrystEngComm 2008, 10, 784. [CrossRef]

2. Tong, M.L.; Chen, X.M. Chapter 8-Synthesis of Coordination Compounds and Coordination Polymers. In Modern Inorganic Synthetic Chemistry, 2nd ed.; Xu, R., Xu, Y., Eds.; Elsevier: Amsterdam, The Netherlands, 2017; pp. 189-217.

3. Cheong, V.F.; Moh, P.Y. Recent advancement in metal-organic framework: Synthesis, activation, functionalisation, and bulk production. Mater. Sci. Technol. 2018, 34, 1025-1045. [CrossRef]

4. Gu, J.; Wen, M.; Liang, X.; Shi, Z.-F.; Kirillova, M.V.; Kirillov, A.M. Multifunctional Aromatic Carboxylic Acids as Versatile Building Blocks for Hydrothermal Design of Coordination Polymers. Crystals 2018, 8, 83. [CrossRef]

5. Liu, R.; Zhang, W.; Chen, Y.; Wang, Y. Uranium (VI) adsorption by copper and copper/iron bimetallic central MOFs. Colloids Surfaces A Physicochem. Eng. Asp. 2020, 587, 124334. [CrossRef]

6. Li, J.; Li, W.-J.; Xu, S.-C.; Li, B.; Tang, Y.; Lin, Z.-F. Porous metal-organic framework with Lewis acid-base bifunctional sites for high efficient $\mathrm{CO} 2$ adsorption and catalytic conversion to cyclic carbonates. Inorg. Chem. Commun. 2019, 106, 70-75. [CrossRef] 
7. Yu, M.-H.; Space, B.; Franz, D.M.; Zhou, W.; He, C.; Li, L.; Krishna, R.; Chang, Z.; Li, W.; Hu, T.-L.; et al. Enhanced Gas Uptake in a Microporous Metal-Organic Framework via a Sorbate Induced-Fit Mechanism. J. Am. Chem. Soc. 2019, 141, 17703-17712. [CrossRef] [PubMed]

8. Huang, X.H.; Shi, L.; Ying, S.M.; Yan, G.Y.; Liu, L.H.; Sun, Y.Q.; Chen, Y.P. Two lanthanide metal-organic frameworks as sensitive luminescent sensors for the detection of $\mathrm{Cr}^{2+}$ and $\mathrm{Cr}_{2} \mathrm{O}_{7}{ }^{2-}$ in aqueous solutions. CrystEngComm 2018, 20, 189-197. [CrossRef]

9. Chiu, C.-C.; Shieh, F.-K.; Tsai, H.-H.G. Ligand Exchange in the Synthesis of Metal-Organic Frameworks Occurs Through Acid-Catalyzed Associative Substitution. Inorg. Chem. 2019, 58, 14457-14466. [CrossRef]

10. Parmar, B.; Patel, P.; Pillai, R.S.; Tak, R.K.; Kureshy, R.; Khan, N.-U.H.; Suresh, E. Cycloaddition of CO2 with an Epoxide-Bearing Oxindole Scaffold by a Metal-Organic Framework-Based Heterogeneous Catalyst under Ambient Conditions. Inorg. Chem. 2019, 58, 10084-10096. [CrossRef]

11. Xie, W.; Tian, M.; Luo, X.; Jiang, Y.; He, N.; Liao, X.; Liu, Y. A dual-mode fluorescent and colorimetric immunoassay based on in situ ascorbic acid-induced signal generation from metal-organic frameworks. Sensors Actuators B Chem. 2020, 302, 127180. [CrossRef]

12. Wiwasuku, T.; Boonmak, J.; Siriwong, K.; Ervithayasuporn, V.; Youngme, S. Highly sensitive and selective fluorescent sensor based on a multi-responsive ultrastable amino-functionalized $\mathrm{Zn}$ (II)-MOF for hazardous chemicals. Sensors Actuators B Chem. 2019, 284, 403-413. [CrossRef]

13. Wang, J.-J.; Bao, Q.-L.; Chen, J. Two 2-D layered coordination polymers based on 5-aminoisophthalate and 1,10-phenanthroline. J. Coord. Chem. 2013, 66, 2578-2586. [CrossRef]

14. Kan, M.-Y.; Shin, J.H.; Yang, C.-T.; Chang, C.-K.; Lee, L.-W.; Chen, B.-H.; Lu, K.-L.; Lee, J.S.; Lin, L.-C.; Kang, D.-Y. Activation-Controlled Structure Deformation of Pillared-Bilayer Metal-Organic Framework Membranes for Gas Separations. Chem. Mater. 2019, 31, 7666-7677. [CrossRef]

15. Peterson, G.W.; Au, K.; Tovar, T.M.; Epps, T.H.; Epps, T.H. Multivariate CuBTC Metal-Organic Framework with Enhanced Selectivity, Stability, Compatibility, and Processability. Chem. Mater. 2019, 31, 8459-8465. [CrossRef]

16. Wang, J.J.; Si, P.-P.; Yang, J.; Zhao, S.-S.; Li, P.-P.; Li, B.; Wang, S.-Y.; Lu, M.; Yu, S.-X. La(III)-based MOFs with 5 -aminoisophthalic acid for optical detection and degradation of organic molecules in water. Polyhedron 2019, 162, 255-262. [CrossRef]

17. Xu, W.-Q.; He, S.; Liu, S.-J.; Liu, X.-H.; Qiu, Y.-X.; Liu, W.-T.; Jiang, L.-C.; Jiang, J.-J. Post-synthetic modification of a metal-organic framework based on 5-aminoisophthalic acid for mercury sorption. Inorg. Chem. Commun. 2019, 108, 107515. [CrossRef]

18. Scholz, G.; Abdulkader, A.; Kemnitz, E. Mechanochemical synthesis and characterization of alkaline earth metal terephthalates: $\mathrm{M}\left(\mathrm{C}_{8} \mathrm{H}_{4} \mathrm{O}_{4}\right) \cdot \mathrm{nH}_{2} \mathrm{O}(\mathrm{M}=\mathrm{Ca}, \mathrm{Sr}, \mathrm{Ba})$. Zeitschrift für Anorganische und Allgemeine Chemie 2014, 640, 317-324. [CrossRef]

19. Niekiel, F.; Stock, N. Discovery of New Calcium Etidronates Employing Ultrasound Adapted High-Throughput Methods. Cryst. Growth Des. 2013, 14, 599-606. [CrossRef]

20. Buchanan, W.D.; Allis, D.; Ruhlandt-Senge, K. Synthesis and stabilization-Advances in organoalkaline earth metal chemistry. Chem. Commun. 2010, 46, 4449. [CrossRef]

21. Asgharnejad, L.; Abbasi, A.; Najafi, M.; Janczak, J. Synthesis and Structure of Three New Alkaline Earth Metal-Organic Frameworks with High Thermal Stability as Catalysts for Knoevenagel Condensation. Cryst. Growth Des. 2019, 19, 2679-2686. [CrossRef]

22. Liu, Y.; Ma, L.-N.; Shi, W.-J.; Lu, Y.-K.; Hou, L.; Wang, Y.-Y. Four alkaline earth metal (Mg, Ca, Sr, Ba)-based MOFs as multiresponsive fluorescent sensors for $\mathrm{Fe}^{3+}, \mathrm{Pb}^{2+}$ and $\mathrm{Cu}^{2+}$ ions in aqueous solution. J. Solid State Chem. 2019, 277, 636-647. [CrossRef]

23. Matlinska, M.A.; Ha, M.; Hughton, B.; Oliynyk, A.O.; Iyer, A.K.; Bernard, G.; Lambkin, G.R.; Lawrence, M.C.; Katz, M.J.; Mar, A.; et al. Alkaline Earth Metal-Organic Frameworks with Tailorable Ion Release: A Path for Supporting Biomineralization. ACS Appl. Mater. Interfaces 2019, 11, 32739-32745. [CrossRef] [PubMed]

24. Harder, S. From Limestone to Catalysis: Application of Calcium Compounds as Homogeneous Catalysts. Chem. Rev. 2010, 110, 3852-3876. [CrossRef]

25. Das, M.C.; Ghosh, S.K.; Sañudo, E.C.; Bharadwaj, P.K. Coordination polymers with pyridine-2,4,6-tricarboxylic acid and alkaline-earth/lanthanide/transition metals: Synthesis and X-ray structures. Dalton Trans. 2009, 9, 1644-1658. [CrossRef] [PubMed] 
26. Diamantis, S.A.; Pournara, A.D.; Hatzidimitriou, A.G.; Manos, M.J.; Papaefstathiou, G.S.; Lazarides, T. Two new alkaline earth metal organic frameworks with the diamino derivative of biphenyl-4, $4^{\prime}$-dicarboxylate as bridging ligand: Structures, fluorescence and quenching by gas phase aldehydes. Polyhedron 2018, 153, 173-180. [CrossRef]

27. Li, Z.; Li, Z.; Li, S.; Wang, K.; Ma, F.; Tang, B. Potential application development of Sr/HCOOH metal organic framework in osteoarthritis. Microporous Mesoporous Mater. 2020, 294, 109835. [CrossRef]

28. Margariti, A.; Pournara, A.D.; Manos, M.J.; Lazarides, T.; Papaefstathiou, G.S. Towards white-light emission by $\mathrm{Tb}^{3+} / \mathrm{Eu}^{3+}$ substitution in a Ca ${ }^{2+}$ framework. Polyhedron 2018, 153, 24-30. [CrossRef]

29. Mazaj, M.; Mali, G.; Rangus, M.; Žunkovič, E.; Kaučič, V.; Logar, N.Z. Spectroscopic Studies of Structural Dynamics Induced by Heating and Hydration: A Case of Calcium-Terephthalate Metal-Organic Framework. J. Phys. Chem. C 2013, 117, 7552-7564. [CrossRef]

30. Wang, X.; San, L.K.; Nguyen, H.; Shafer, N.M.; Hernandez, M.T.; Chen, Z. Alkaline earth metal-organic frameworks supported by ditopic carboxylates. J. Coord. Chem. 2013, 66, 826-835. [CrossRef]

31. Platero-Prats, A.E.; Iglesias, M.; Snejko, N.; Monge, A.; Gutierrez-Puebla, E.; Monge, M.A. From Coordinatively Weak Ability of Constituents to Very Stable Alkaline-Earth Sulfonate Metal-Organic Frameworks. Cryst. Growth Des. 2011, 11, 1750-1758. [CrossRef]

32. Saha, D.; Maity, T.; Das, S.; Koner, S. A magnesium-based multifunctional metal-organic framework: Synthesis, thermally induced structural variation, selective gas adsorption, photoluminescence and heterogeneous catalytic study. Dalton Trans. 2013, 42, 13912. [CrossRef] [PubMed]

33. Saha, D.; Maity, T.; Sen, R.; Koner, S. Heterogeneous catalysis over a barium carboxylate framework compound: Synthesis, X-ray crystal structure and aldol condensation reaction. Polyhedron 2012, 43, 63-70. [CrossRef]

34. Sen, R.; Saha, D.; Koner, S. Controlled Construction of Metal-Organic Frameworks: Hydrothermal Synthesis, X-ray Structure, and Heterogeneous Catalytic Study. Chem. A Eur. J. 2012, 18, 5979-5986. [CrossRef] [PubMed]

35. Zhang, S.; Qu, X.-N.; Xie, G.; Wei, Q.; Chen, S. Syntheses, structural analyses and luminescent property of four alkaline-earth coordination polymers. J. Solid State Chem. 2014, 210, 36-44. [CrossRef]

36. Barbosa, A.; Julião, D.; Fernandes, D.M.; Peixoto, A.F.; Freire, C.; De Castro, B.; Granadeiro, C.; Balula, S.; Cunha-Silva, L. Catalytic performance and electrochemical behaviour of Metal-organic frameworks: MIL-101(Fe) versus NH2-MIL-101(Fe). Polyhedron 2017, 127, 464-470. [CrossRef]

37. Granadeiro, C.; Nogueira, L.; Julião, D.; Mirante, F.; Ananias, D.; Cunha-Silva, L.; Balula, S. Influence of a porous MOF support on the catalytic performance of Eu-polyoxometalate based materials: Desulfurization of a model diesel. Catal. Sci. Technol. 2016, 6, 1515-1522. [CrossRef]

38. Granadeiro, C.; Ribeiro, S.; Karmaoui, M.; Valença, R.; Ribeiro, J.C.; De Castro, B.; Cunha-Silva, L.; Balula, S. Production of ultra-deep sulfur-free diesels using a sustainable catalytic system based on UiO-66(Zr). Chem. Commun. 2015, 51, 13818-13821. [CrossRef]

39. Sousaraei, A.; Queiros, C.; Moscoso, F.G.; Lopes-Costa, T.; Pedrosa, J.M.; Silva, A.; Cunha-Silva, L.; Cabanillas-Gonzalez, J. Subppm Amine Detection via Absorption and Luminescence Turn-On Caused by Ligand Exchange in Metal Organic Frameworks. Anal. Chem. 2019, 91, 15853-15859. [CrossRef]

40. Xu, L.; Liu, B.; Liu, S.-X.; Jiao, H.; De Castro, B.; Cunha-Silva, L. The influence of 1-alkyl-3-methyl imidazolium ionic liquids on a series of cobalt-1,4-benzenedicarboxylate metal-organic frameworks. CrystEngComm 2014, 16, 10649-10657. [CrossRef]

41. Xu, L.; Kwon, Y.-U.; De Castro, B.; Cunha-Silva, L. Novel Mn(II)-Based Metal-Organic Frameworks Isolated in Ionic Liquids. Cryst. Growth Des. 2013, 13, 1260-1266. [CrossRef]

42. Rocha, J.; Shi, F.-N.; Paz, F.A.A.; Mafra, L.; Sardo, M.; Cunha-Silva, L.; Chisholm, J.; Ribeiro-Claro, P.J.A.; Trindade, T. 3D-2D-0D Stepwise Deconstruction of a Water Framework Templated by a Nanoporous Organic-Inorganic Hybrid Host. Chem. A Eur. J. 2010, 16, 7741-7749. [CrossRef] [PubMed]

43. Soares-Santos, P.C.R.; Cunha-Silva, L.; Paz, F.A.A.; Ferreira, R.A.S.; Rocha, J.; Carlos, L.D.; Nogueira, H.I.S. Photo luminescent Lanthanide-Organic Bilayer Networks with 2,3-Pyrazinedicarboxylate and Oxalate. Inorg. Chem. 2010, 49, 3428-3440. [CrossRef] [PubMed]

44. Murugavel, R.; Kumar, P.; Walawalkar, M.G.; Mathialagan, R. A Double Helix Is the Repeating Unit in a Luminescent Calcium 5-Aminoisophthalate Supramolecular Edifice with Water-Filled Hexagonal Channels. Inorg. Chem. 2007, 46, 6828-6830. [CrossRef] [PubMed] 
45. Kuang, R.Y.; Zhou, X.C.; Liu, L.J.; Lin, J.Y. A new 1D coordination polymer constructed by CaCl2 with 5-aminoiosphtalic acid (H2AIP) and 1,10-phenanthroline ligands using the water bath method. Russ. J. Coord. Chem. 2010, 36, 918-922. [CrossRef]

46. Wu, C.-Y.; Lin, C.-H. Poly[([mu]5-5-aminoisophthalato)aquabarium]. Acta Cryst. B 2011, 67, 1413.

47. Kottke, T.; Stalke, D. Crystal handling at low temperatures. J. Appl. Crystallogr. 1993, 26, 615-619. [CrossRef]

48. APEX2, Data Collection Software Version 2.1-RC13; Bruker AXS: Delft, The Netherlands, 2006.

49. SAINT+, Data Integration Engine v. 7.23a ${ }^{\circledR}$; Bruker AXS: Madison, WI, USA, 1997-2005.

50. Sheldrick, G.M. SADABS v.2.01, Bruker/Siemens Area Detector Absorption Correction Program; Bruker AXS: Madison, WI, USA, 1998.

51. Sheldrick, G.M. A short history ofSHELX. Acta Crystallogr. Sect. A Found. Crystallogr. 2007, 64, 112-122. [CrossRef]

52. Sheldrick, G.M. SHELXS-97, Program for Crystal Structure Solution; University of Göttingen: Göttingen, Germany, 1997.

53. Sheldrick, G.M. SHELXL-97, Program for Crystal Structure Refinement; University of Göttingen: Göttingen, Germany, 1997.

Sample Availability: Most of the samples of the compounds are available from the authors. 